\title{
The impact of monsoon outflow from India and Southeast Asia in the upper troposphere over the eastern Mediterranean
}

\author{
H. A. Scheeren ${ }^{1,2}$, J. Lelieveld ${ }^{2}$, G. J. Roelofs ${ }^{1}$, J. Williams ${ }^{2}$, H. Fischer ${ }^{2}$, M. de Reus ${ }^{2}$, J. A. de Gouw ${ }^{1,3}$, \\ C. Warneke ${ }^{1,3}$, R. Holzinger ${ }^{2}$, H. Schlager ${ }^{4}$, T. Klüpfel ${ }^{2}$, M. Bolder ${ }^{1}$, C. van der Veen ${ }^{1}$, and M. Lawrence ${ }^{2}$ \\ ${ }^{1}$ Institute for Marine and Atmospheric Research Utrecht (IMAU), Utrecht University, The Netherlands \\ ${ }^{2}$ Max Planck Institute for Chemistry, Mainz, Germany \\ ${ }^{3}$ now at NOAA Aeronomy Laboratory, Boulder, Colorado, USA \\ ${ }^{4}$ Institute for Atmospheric Physics, DLR, Oberpfaffenhofen, Germany
}

Received: 5 February 2003 - Published in Atmos. Chem. Phys. Discuss.: 12 May 2003

Revised: 12 September 2003 - Accepted: 23 September 2003 - Published: 1 October 2003

\begin{abstract}
A major objective of the Mediterranean INtensive Oxidant Study (MINOS) was to investigate long-range transport of pollutants (notably ozone precursor species). Here we present trace gas measurements from the DLR (German Aerospace Organization) Falcon aircraft in the eastern Mediterranean troposphere. Ten day backward trajectories and a coupled chemistry-climate model (ECHAM4) were used to study the nature and origin of pollution observed in the upper troposphere between 6 and $13 \mathrm{~km}$ altitude. We focus on a large pollution plume encountered over the eastern Mediterranean between 1 and 12 August originating in South Asia (India and Southeast Asia), referred to as the Asian plume, associated with the Asian Summer Monsoon. Vertical as well as longitudinal gradients of methane, carbon monoxide, hydrocarbons including acetone, methanol, and acetonitrile, halocarbons, ozone and total reactive nitrogen $\left(\mathrm{NO}_{\mathrm{y}}\right)$ are presented, showing the chemical impact of the Asian plume compared to westerly air masses containing pollution from North America. The Asian plume is characterized by enhanced concentrations of biomass burning tracers (acetylene, methyl chloride, acetonitrile), notably from biofuel use. Concentrations of the new automobile cooling agent HFC-134a were significantly lower in the Asian plume than in air masses from North America. Relatively high levels of ozone precursors ( $\mathrm{CO}$, hydrocarbons) were found in both air masses, whereas lower ozone concentrations in the Asian plume suggest $\mathrm{NO}_{\mathrm{x}}$-limited conditions. Consistently, ECHAM model simulations indicate that the expected future increase of $\mathrm{NO}_{\mathrm{x}}$-emissions in Asia enhances the photochemical ozone production in the Asian plume. The size and location of the Asian plume near the tropopause provides an important potential for pollution transport into the lowermost stratosphere. We present observations indicative of Asian pollution transport into the lower stratosphere.
\end{abstract}

Correspondence to: H. A. Scheeren

(h.a.Scheeren@phys.uu.nl)

\section{Introduction}

Observations and model work have indicated that the summertime Mediterranean stands out as one of the most polluted regions on earth in terms of photochemical ozone formation and aerosol loading (Kouvarakis et al., 2000; Lelieveld and Dentener, 2000). The MINOS project (Mediterranean Intensive Oxidant Study) was initiated to improve our understanding of the transport processes, chemical mechanisms and main pollution sources that determine the chemical composition in the eastern Mediterranean troposphere. As a result, an intensive field campaign was carried out from Crete during August 2001 involving a ground station (Finokalia; $35.19^{\circ} \mathrm{N}, 25.40^{\circ} \mathrm{E}$ ) and two aircraft to perform measurements of a wide range of trace gases and aerosols. An overview of major findings of MINOS is presented by Lelieveld et al. (2002).

A major objective of MINOS was to examine the role of long-range transport of pollutants into the region, notably to observe outflow from the southern Asian Summer Monsoon (ASM hereafter) over the eastern Mediterranean. The Asian plume, which also influences the Indian Ocean troposphere as found during the 1999 Indian Ocean Experiment (INDOEX) (Lelieveld et al., 2001), contains high concentrations of ozone precursors (e.g. carbon monoxide (CO), nonmethane hydrocarbons (NMHC)), partly oxidized hydrocarbons (e.g. acetone $\left(\mathrm{CH}_{3} \mathrm{COCH}_{3}\right)$, methanol $\left.\left(\mathrm{CH}_{3} \mathrm{OH}\right)\right)$ ) and chlorocarbons (notably methyl chloride $\left(\mathrm{CH}_{3} \mathrm{Cl}\right)$ ) (Scheeren et al., 2002), as well as aerosols from fossil fuel and biomass burning emissions from the densely populated South Asian region. The less soluble species can be effectively transported to the upper troposphere by deep convection in the ASM. High altitude easterlies can carry Asian pollution across northern Africa and the Mediterranean. Indeed, back-trajectories (Traub et al., 2003) and model simulations (Lawrence et al., 2003; Roelofs et al., 2003) indicate that the 
eastern Mediterranean upper troposphere ( $>9 \mathrm{~km}$ altitude) was dominated by a southeasterly flow originating over India and southeast Asia during the first half of August. During the second half of August the easterly flow weakened, after which a westerly flow dominated the upper troposphere, advecting air masses from the Atlantic region and North America to the MINOS region. Furthermore, the middle to upper tropospheric westerlies appeared to be regularly affected by downward transport of ozone-rich air from stratospheric origin (Roelofs et al., 2003; Heland et al., 2003).

Here we report on trace gas measurements performed with a German Falcon jet aircraft, which operated from Heraklion airport $\left(35^{\circ} \mathrm{N}, 25^{\circ} \mathrm{E}\right)$. A total of 14 flights was conducted from the boundary layer up to $13 \mathrm{~km}$, mainly over the Aegean Sea. In this study, we focus on the eastern Mediterranean upper troposphere between 6 and $13 \mathrm{~km}$ altitude. The measurement techniques are described in Sect. 2. We discuss the dynamics of the eastern Mediterranean troposphere during MINOS in Sect. 3. In Sect. 4 we show tropospheric distributions of $\mathrm{C}_{2}-\mathrm{C}_{7} \mathrm{NMHC}$, halocarbons (including new anthropogenic halocarbons HFC-134a $\left(\mathrm{CH}_{2} \mathrm{FCF}_{3}\right)$, HCFC-141b $\left(\mathrm{CH}_{3} \mathrm{CCl}_{2} \mathrm{~F}\right)$, and HCFC-142b $\left.\left(\mathrm{CH}_{3} \mathrm{CClF}_{2}\right)\right)$, $\mathrm{CO}$, carbon dioxide $\left(\mathrm{CO}_{2}\right)$, methane $\left(\mathrm{CH}_{4}\right)$, ozone $\left(\mathrm{O}_{3}\right)$, organic species (acetone, methanol and acetonitrile $\left(\mathrm{CH}_{3} \mathrm{CN}\right)$ ), and nitrogen oxide (NO) and $\mathrm{NO}_{y}$ (sum of reactive oxidized nitrogen; mainly $\mathrm{NO}+\mathrm{NO}_{2}+\mathrm{NO}_{3}+\mathrm{N}_{2} \mathrm{O}_{5}+\mathrm{HNO}_{4}+\mathrm{HNO}_{3}+\mathrm{RONO}_{2}$ + peroxy acetyl nitrate (PAN)). We examine the upper tropospheric chemistry in the Asian plume and compare this with westerly air masses originating over the Atlantic and North American region and with results from INDOEX. Furthermore, observations of Asian pollution transport into the lower stratosphere are presented in Sect. 5.

In addition, we use a coupled tropospheric chemistryclimate model (ECHAM4; see Roelofs et al., 2003) to analyze contributions of the different origins or source regions of ozone, $\mathrm{CO}$, and $\mathrm{NMHC}$ in the upper troposphere during MINOS presented in Sect. 6. Finally, the possible impact of future Asian emissions of $\mathrm{NMHC}, \mathrm{CO}$ and $\mathrm{NO}_{\mathrm{x}}\left(\mathrm{NO}+\mathrm{NO}_{2}\right)$ on tropospheric ozone is discussed.

\section{Measurements techniques}

First we summarize the measurements techniques employed and report the uncertainty and precision of the data presented. The in-situ measurements and air sample collection were performed on-board the German Falcon twin-jet research aircraft (operated by the German Aerospace Center (DLR)), using forward facing inlets on top of the aircraft fuselage. The Max-Planck Institute for Chemistry (MPI-C) provided the Tunable Diode Laser Spectrometry (TDLAS) instrument to measure $\mathrm{CO}, \mathrm{CO}_{2}$ and $\mathrm{CH}_{4}$ with a $1 \mathrm{~s}$ time resolution, at $1 \sigma$ precision of $1.5 \mathrm{ppbv}\left(\mathrm{nmol} \mathrm{mol}{ }^{-1}\right), 1.5 \mathrm{ppmv}(\mu \mathrm{mol}$ $\mathrm{mol}^{-1}$ ), and $16.5 \mathrm{ppbv}$, respectively, and an absolute accuracy of $\pm 1 \%$ for all species (Wienhold et al., 1998).

The DLR performed the measurements of $\mathrm{NO}, \mathrm{NO}_{\mathrm{y}}$ (total oxidized nitrogen species) as well as $\mathrm{O}_{3}$, which are described in detail by Heland et al. (2003). Ozone was detected by means of UV absorption using a modified Thermo Environmental 49 monitor from the DLR at a time resolution of $4 \mathrm{~s}$. Accuracy and $1 \sigma$ precision are $\sim 1 \mathrm{ppbv}$ and $\pm 5 \%$, respectively. NO is measured with a well characterized ECO Physics CLD 790 SR chemiluminescence detector (CLD), $\mathrm{NO}_{\mathrm{y}}$ is measured with a second CLD in combination with a gold converter at $300^{\circ} \mathrm{C}$ with $\mathrm{CO}(0.2 \%)$ as the reduction agent (Ziereis et al., 1999). Both $\mathrm{NO}$ and $\mathrm{NO}_{\mathrm{y}}$ were measured at a $1 \mathrm{~Hz}$ time resolution. The detection limits of the instruments are 5 pptv for $\mathrm{NO}$, and $15 \mathrm{pptv}$ for $\mathrm{NO}_{\mathrm{y}}$. The nominal accuracies of the $\mathrm{NO}$ and $\mathrm{NO}_{\mathrm{y}}$ measurements are $5 \%$ and $15 \%$, respectively.

The measurements of acetone, methanol and acetonitrile reported here, were carried out using a Proton-TransferReaction Mass-Spectrometer (PTR-MS) from NOAA Aeronomy Laboratory (Boulder, Colorado) with a $12 \mathrm{~s}$ time resolution. A precision of $\pm 30 \%$ and a calibration uncertainty better than $\pm 20 \%$ were achieved. Peroxy acetyl nitrate (PAN) was detected with an additional PTR-MS operated by the MPI-C at and an uncertainty of $\sim 50 \%$. For details about the PTR-MS technique we refer to Lindinger et al. (1998) and de Gouw et al. (2003).

Non-methane hydrocarbons and halocarbons were detected in whole air samples collected in $2.4 \mathrm{~L}$ electropolished pre-cleaned stainless steel canisters equipped with Swagelok Nupro SS4H valves. An automated airborne sampling system suitable for filling 12 canisters per flight, resulted in a time resolution of about 1 air sample per $15 \mathrm{~min}$ of flight (Scheeren et al., 2002). A total of 103 canisters were filled on flight 2 to 11 and 13 (no canisters were filled on flight 1 (1 August) due to a system malfunctioning, and on flight 12 and 14 (22 August) because of a limited amount of canisters). To limit storage artifacts, the air samples were analyzed within a few weeks after collection. The analysis was performed at the IMAU laboratory using a gas chromatograph (GC; Varian star 3600 CX) equipped with a CP-Sil 5 CB pre-column (WCOT Fused Silica, $0.53 \mathrm{~mm}$ I.D.; $10 \mathrm{~m}$ long) in series with a CP-SilicaPLOT column (PLOT Fused Silica, $0.53 \mathrm{~mm}$ I.D.; $60 \mathrm{~m}$ long) and detection by Flame Ionization Detection (hydrocarbons and $\mathrm{CH}_{3} \mathrm{Cl}$ ) and Electron Capture Detection (halocarbons). We note that we used the FID instead of the $\mathrm{ECD}$ for quantitative evaluation of $\mathrm{CH}_{3} \mathrm{Cl}$ to improve the precision. Pre-concentration of a 1-L sample was done with a Varian Sample Pre-concentration Trap (SPT) at a freezeout temperature of $-170^{\circ} \mathrm{C}$ at a flow rate of $33 \mathrm{ml} \mathrm{min}-1$ regulated by a mass flow controller. The reproducibility of the SPT with standard gas is better than $2 \%(1 \sigma)$. Before entering the SPT, water was removed from the sample stream by passing it through a Nafion drier tube mounted inside a countercurrent flow of purified dry nitrogen. Tests with the 

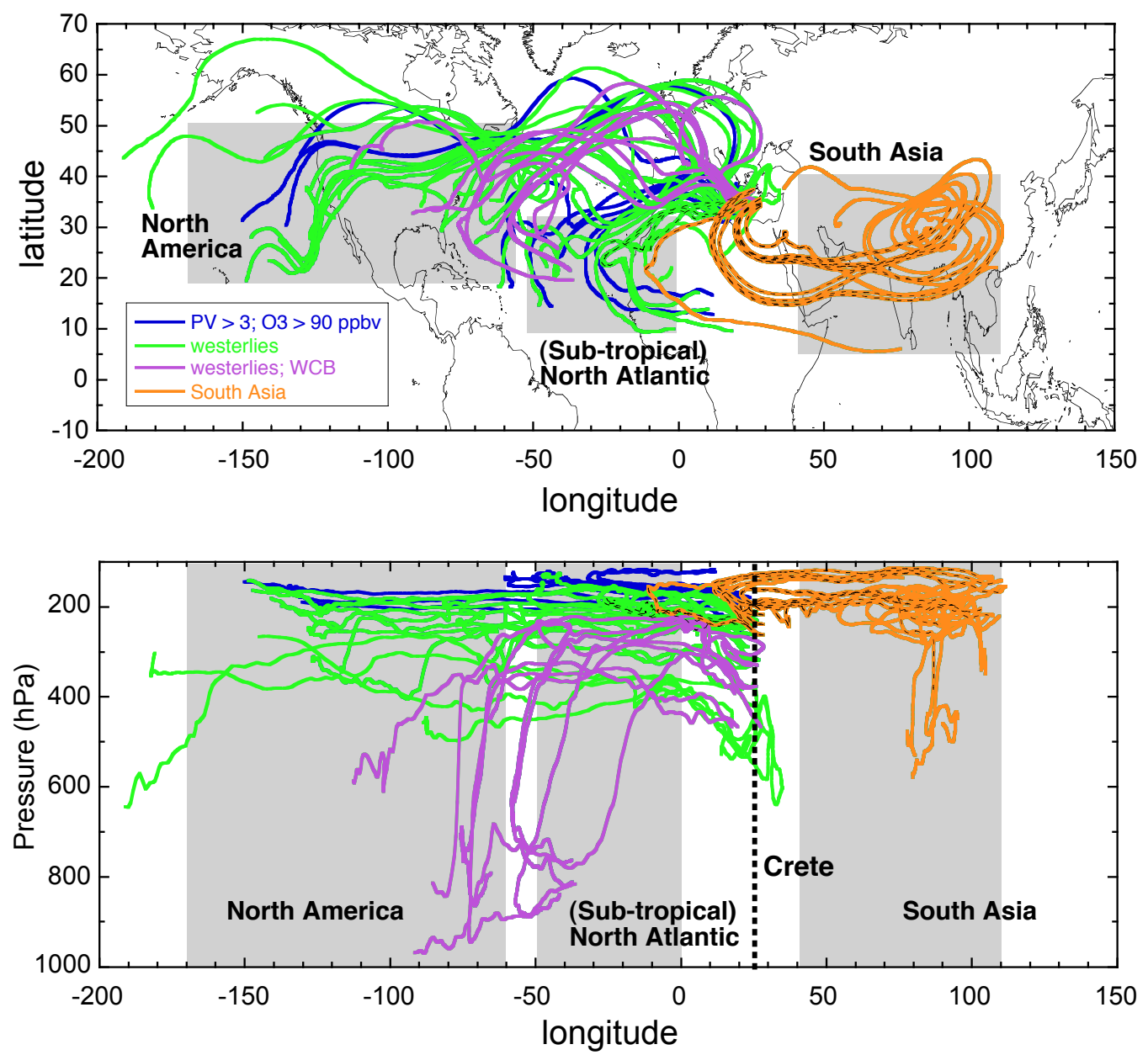

Fig. 1. Results from a 10-day backward trajectory analysis based on ECMWF wind fields. The trajectories were computed for the times and locations of air samples collected during 2 and 22 August ( 1 to 2 trajectories per flight level of $\sim 15$ min). The shaded areas denote the air mass origins, being North America, the (subtropical) North Atlantic and South Asia. Orange trajectories relate to South Asia (dashed lines denote 5 days backward), in light green westerly trajectories ending between 8 and $12 \mathrm{~km}$ altitude are shown, in purple between 6 and $9 \mathrm{~km}$. Blue trajectories indicate air masses which have been subject to stratosphere-troposphere exchange based on their PV-history.

Nafion tube indicated no artifacts for the hydro- and halocarbons species presented in this study. Here we show results for $\mathrm{C}_{2}-\mathrm{C}_{5}$ hydrocarbons, benzene and toluene, and halocarbons $\mathrm{CH}_{3} \mathrm{Cl}$, dichloromethane $\left(\mathrm{CH}_{2} \mathrm{Cl}_{2}\right)$, trichloromethane (chloroform, $\mathrm{CHCl}_{3}$ ), tetrachloroethylene $\left(\mathrm{C}_{2} \mathrm{Cl}_{4}\right)$, $\mathrm{CFC}-12$ $\left(\mathrm{CF}_{2} \mathrm{Cl}_{2}\right), \mathrm{CFC}-11\left(\mathrm{CFCl}_{3}\right)$, HFC-134a $\left(\mathrm{CH}_{2} \mathrm{FCF}_{3}\right), \mathrm{HCFC}-$ $141 \mathrm{~b}\left(\mathrm{CH}_{3} \mathrm{CCl}_{2} \mathrm{~F}\right)$, and HCFC-142b $\left(\mathrm{CH}_{3} \mathrm{CClF}_{2}\right)$. The detection limit for hydrocarbons is $<3 \mathrm{pptv}\left(\mathrm{pmol} \mathrm{mol}^{-1}\right)$, for $\mathrm{CH}_{3} \mathrm{Cl}$ (on the FID) and $\mathrm{CH}_{2} \mathrm{Cl}_{2}<10 \mathrm{pptv}$, and for the other halocarbons $<0.1 \mathrm{pptv}$. Calibration was performed on a routine basis, using commercial gravimetrically prepared standard gas mixtures of hydrocarbons and halocarbons in nitrogen gas (PRAXAIR) as reference air with an accuracy of $<3 \%$ for hydrocarbons and $<2 \%$ for halocarbons. The halocarbons standard mixture has been additionally calibrated against primary standards at the Netherlands Metrology Institute (NMI). The halocarbons HFC-134a, HCFC-141b and
HCFC-142b were detected and calibrated on the basis of reference samples provided by S. A. Montzka of NOAA, CMDL (Boulder, CO, USA) resulting in an accuracy $<5 \%$. The overall precision was $<10 \%$ for the NMHC and $<3 \%$ for the remaining halocarbons except for $\mathrm{CH}_{2} \mathrm{Cl}_{2}(<15 \%)$ due to its poor detector response.

\section{Free tropospheric meteorology}

We used 10-day back trajectories calculated by the Royal Netherlands Meteorological Institute (KNMI) to study longrange transport routes and the origin of the encountered air masses. The trajectory model uses analyzed (6-hour averaged) 3-D wind fields from the European Centre for Medium-range Weather Forecast (ECMWF) (Scheele et al., 1996; Stohl et al., 2001). Back trajectories were computed 
for each time a canister sample was taken, resulting in a set of trajectories that indicate the major transport pathways into the region. Here, we focus on the middle to upper troposphere between 6 to $13 \mathrm{~km}$ altitude dominated by long-range transport. For an outline of transport pathways and chemical characteristics of air masses encountered in the entire troposphere including the boundary layer we refer to Lelieveld et al. (2002) and Traub et al. (2003).

An overview of 10-day back trajectories for air masses encountered above $6 \mathrm{~km}$ altitude between 3 and 22 August (flight 2 to 11 and 13) is presented in Fig. 1. Shown are trajectories as a function of latitude and longitude (upper panel) and as a function of pressure and longitude (lower panel). Between 6 and $9 \mathrm{~km}$ we occasionally found polluted air (purple trajectories) originating below $700 \mathrm{hPa}$ over the eastern United States and the eastern Atlantic region (roughly between $60^{\circ}$ and $90^{\circ} \mathrm{W}$ ), 5 to 10 days prior to the flight. These polluted layers (discussed in Sect. 4.1) appear to be the results of fast upward motion associated with warm conveyor belt (WCB) transport ahead of a cold front (Stohl and Trickl, 1999). In green are tropospheric air masses encountered between 8 and $12 \mathrm{~km}$ altitude, which were dominated by westerlies from North America and the North Atlantic region up to about $9 \mathrm{~km}$. Above $9 \mathrm{~km}$ altitude a southeasterly flow prevailed during the first two weeks of August, originating in South Asia (India and Southeast Asia), which is referred to as the Asian plume, shown as orange trajectories (superimposed dashed lines denote 5 days back in time).

During July and August the South Asian region (India, Pakistan, and the Bay of Bengal area) is subject to the Asian summer monsoon (ASM). Satellite images (GOES5 visible and infrared channel; http://www.eumetsat.de/en/ dps/archive/historic.html) show a strong monsoonal activity through the presence of large clusters of convective clouds over India and the Bay of Bengal 10-15 days prior to the easterly plume in the Mediterranean upper troposphere between 1 and 12 July 2001. The ASM is associated with one of the largest upper tropospheric anti-cyclones on earth present from May to September. It has been the subject of intense study for over 150 years (Hastenrath, 1991; Hsu et al., 1999). The ASM is triggered in May. The Tibetan plateau starts to heat up after winter and an upper tropospheric anticyclone is formed through upward motion of warm air over the Central Asian mountain range. The warming causes a reversal of the meridional temperature gradient towards the Indian Ocean region, which redirects the low-level northeasterly winds into a southwesterly direction and the upper tropospheric subtropical westerly jet into an easterly direction (Hsu et al., 1999). Deep convection associated with the ASM can carry polluted Asian boundary layer air into the upper tropospheric anti-cyclonic circulation. Thus, pollution from South Asia is transported in the upper troposphere over Africa and the Mediterranean along with the easterly tropical jet (Fig. 1; orange trajectories), in conjunction with an upper tropospheric anticyclone over the Arabian Peninsula. During the second half of August 2001, the position of the Arabian anticyclone shifted to the southeast, reducing the influence of the Asian plume over the eastern Mediterranean.

Model work indicates that stratosphere-to-troposphereexchange (STE) associated with the passing of cold fronts over the North Atlantic may contribute about $30 \%$ of the ozone in the westerlies (Roelofs et al., 2003). Air mass trajectories associated with STE are shown in blue, where we assume that a potential vorticity value that exceeds 3.0 potential vorticity (PV) units (1 PV-unit $=10^{-6} \mathrm{~km}^{2} \mathrm{~kg}^{-1} \mathrm{~s}^{-1}$ ) anywhere along the 10-day trajectory in combination with ozone concentrations larger than $90 \mathrm{ppbv}$, indicates a STE event.

An additional potential source of pollution in the Mediterranean free troposphere is convection of polluted air boundary layer air over continental areas to the free troposphere, associated with synoptic disturbances or with thunderstorms. An event of fresh pollution lifted up to an altitude of $6 \mathrm{~km}$, associated with thunderstorm activity over eastern Turkey was encountered on 3 August (flight 2) and will be discussed in more detail in Sect. 4.1. An unique example of deep convective injection of polluted air into the tropopause region has been observed on 22 August and is described in detail by Fischer et al. (2003). Here, sharp increases of tropospheric pollutants (e.g. $\mathrm{CO}$, acetone, methanol and acetonitrile) were detected during ascent into the lower stratosphere above the anvil of a large thunderstorm system. Apart from these examples, the impact of deep convective events over the Mediterranean during MINOS in the upper troposphere appears to be rather small compared to the long-range transport of pollution into the region. This is caused by prevailing large scale subsidence in the descending branch of the Hadley circulation, which lies directly over the region and the relative stability of the free troposphere induced by the UT anti-cyclone (Roelofs et al., 2003).

\subsection{Air mass classification}

Air masses have been classified according to their geographical location 7-10 days back in time deduced from the 10-day backward trajectories presented in Fig. 1. Air masses originating between $50^{\circ}$ to $170^{\circ} \mathrm{W}$ and $20^{\circ}$ to $50^{\circ} \mathrm{N}$ were classified as North American; those with an origin between $0^{\circ}$ to $50^{\circ} \mathrm{W}$ and $10^{\circ}$ to $30^{\circ} \mathrm{N}$ as (sub-tropical) North Atlantic, and air masses coming from $40^{\circ}$ to $110^{\circ} \mathrm{E}$ and $5^{\circ}$ to $40^{\circ} \mathrm{N}$ were classified as South Asian. A stratospheric origin was determined by a $\mathrm{PV}>3$ along the trajectory in combination with an ozone concentration exceeding $90 \mathrm{ppbv}$.

A general point of concern is the accuracy of computed trajectories, which decreases with time and increasing geographical scales (Scheele et al., 1995; Stohl, 1998). For instance, Stohl (1998) estimated position errors up to $20 \%$ of the travel distance. In this study we focus on, however, largescale motions in the middle to upper troposphere as well as large-scale lifting events associated with the ASM and the 
WCB in order to distinguish between easterly or westerly air mass origin. In addition, we find good agreement with another more detailed trajectory analysis of the MINOS flights by Traub et al. (2003), who computed 5-day backward trajectories at an one minute time resolution along the flight track.

Based on the number of selected trajectories (55) for air masses between 6 and $13 \mathrm{~km}$ altitude in Fig. 1, we could classify $38 \%$ of the air masses as North American, $14 \%$ as North Atlantic, $24 \%$ as South Asian, and $14 \%$ as stratospheric. The remaining $9 \%$ were associated with other source regions. Hence, we can distinguish two major source regions, i.e., the South Asian and the North American/North Atlantic region with possible pollution transport towards the eastern Mediterranean upper troposphere. In the following sections, we will focus on the comparison of the chemical characteristics of the Asian plume and the westerly air masses of North American and North Atlantic origin.

\section{Chemical characteristics of the free troposphere}

\subsection{Vertical distribution of trace gases}

We present altitude profiles of a number of gaseous trace species measured between 3 and 22 August over the eastern Mediterranean from the boundary layer to about $13 \mathrm{~km}$ altitude in Fig. 2. All data points, except for NMHC and halocarbons from the canister analysis, correspond to the mean of $\sim 5 \mathrm{~min}$ in-situ measurements coinciding with the filling of a canister (1-2 per flight level of $\sim 15 \mathrm{~min}$ ), while the error bars reflect the measured variability ( $1 \sigma$ standard deviation). Color coding denotes the air mass origin above $6 \mathrm{~km}$ altitude based on 10-day backward trajectories (Sect. 3). Air masses from South Asia are depicted in orange, dark green relates to the North Atlantic region, light green squares show the air masses originating over North America, purple squares correspond to air masses in the WCB over the eastern North Atlantic region (lower panel, Fig. 1) and in red pollution from local deep convection is shown (explained in more detail later). Air masses below $\sim 6 \mathrm{~km}$ are depicted in gray. They have not been classified with respect to their origin, but back-trajectory analysis by Traub et al. (2003) shows that European emissions play an important role. For a detailed chemical characterization of boundary layer pollution from European sources during MINOS we refer to Gros et al. (2003). Gray squares in the upper troposphere relate to air masses, which have been influenced by stratospheretroposphere exchange. Table 1 gives an overview of mean concentrations (and $1 \sigma$ standard deviation) in the upper troposphere $(\geq 6 \mathrm{~km})$ of the data presented in Fig. 1 for air masses originating in the North American/North Atlantic region and the South Asian region. For detailed aerosol properties in the troposphere during MINOS we refer to Minikin et al. (2002). We note that aerosol number concentrations
Table 1. Means and $1 \sigma$ standard deviation of trace gas concentrations observed in the upper troposphere $(6-13 \mathrm{~km}$ altitude) for different air mass origins based on 10-day backward trajectory analysis. Air masses with a recent history of stratosphere-to-troposphere exchange were excluded from the data set. The regions of origin are $0^{\circ}-170^{\circ} \mathrm{W}$ by $20^{\circ}-50^{\circ} \mathrm{N}$ for North America/North Atlantic and $40^{\circ}-110^{\circ} \mathrm{E}$ by $5^{\circ}-40^{\circ} \mathrm{N}$ for South Asia

\begin{tabular}{|c|c|c|}
\hline Species & $\begin{array}{l}\text { North America/ } \\
\text { North Atlantic }\end{array}$ & South Asia \\
\hline $\mathrm{O}_{3} \mathrm{ppbv}$ & $73(18)$ & $57(8)$ \\
\hline CO ppbv & $74(12)$ & $102(4)$ \\
\hline $\mathrm{CO}_{2} \mathrm{ppmv}$ & $368(3)$ & $362(2)$ \\
\hline $\mathrm{CH}_{4} \mathrm{ppbv}$ & $1819(26)$ & $1882(21)$ \\
\hline NO ppbv & $0.1(0.08)$ & $0.1(0.05)$ \\
\hline NOy ppbv & $0.75(0.34)$ & $0.59(0.14)$ \\
\hline PAN pptv & $278(144)$ & $328(71)$ \\
\hline $\mathrm{H}_{2} \mathrm{O}$-vapor g/kg & $0.23(0.27)$ & $0.05(0.04)$ \\
\hline $\mathrm{CH}_{3} \mathrm{OH}$ pptv & $610(308)$ & 1006 (199) \\
\hline $\mathrm{CH}_{3} \mathrm{CN}$ pptv & $126(12)$ & $168(32)$ \\
\hline $\mathrm{CH}_{3} \mathrm{COCH}_{3}$ pptv & 957 (331) & 1093 (106) \\
\hline $\mathrm{C}_{2} \mathrm{H}_{6} \mathrm{pptv}$ & $319(72)$ & $448(57)$ \\
\hline $\mathrm{C}_{2} \mathrm{H}_{2}$ pptv & $44(36)$ & $186(44)$ \\
\hline $\mathrm{C}_{3} \mathrm{H}_{8} \mathrm{pptv}$ & $54(39)$ & $58(13)$ \\
\hline $\mathrm{n}-\mathrm{C}_{4} \mathrm{H}_{10} \mathrm{pptv}$ & $12(11)$ & $8(2)$ \\
\hline $\mathrm{n}-\mathrm{C}_{5} \mathrm{H}_{12} \mathrm{pptv}$ & $6(8)$ & $2(1)$ \\
\hline $\mathrm{C}_{6} \mathrm{H}_{6}$ pptv & $11(19)$ & $14(5)$ \\
\hline $\mathrm{C}_{7} \mathrm{H}_{8} \mathrm{pptv}$ & $3(3)$ & $1(1)$ \\
\hline $\mathrm{C}_{2}-\mathrm{C}_{7} \mathrm{ppbC}$ & $1.15(0.48$ & $1.65(0.26)$ \\
\hline $\mathrm{CH}_{3} \mathrm{Cl}$ pptv & 576 (19) & $675(22)$ \\
\hline $\mathrm{CH}_{2} \mathrm{Cl}_{2}$ pptv & $20(6)$ & $23(3)$ \\
\hline $\mathrm{CHCl}_{3} \mathrm{pptv}$ & $5.4(1.4)$ & $7.6(1.0)$ \\
\hline $\mathrm{C}_{2} \mathrm{Cl}_{4} \mathrm{pptv}$ & $1.8(1.3)$ & $1.0(0.3)$ \\
\hline CFC-12 pptv & $561(12)$ & $551(5)$ \\
\hline CFC-11 pptv & $263(8)$ & $270(3)$ \\
\hline HFC-134a pptv & $25.0(3.4)$ & $19.0(2.2)$ \\
\hline HCFC-142b pptv & $13.6(1.7)$ & $13.0(1.7)$ \\
\hline HCFC-141b pptv & $14.0(4.7)$ & $13.5(2.4)$ \\
\hline
\end{tabular}

were not particularly enhanced in the upper troposphere, although relatively high number concentrations of freshly produced Ultrafine Condensation Nuclei (UCN; between 5 and $14 \mathrm{~nm}$ particle diameter) of 1000 to 4000 particle $\mathrm{cm}^{-3}$ (stp) were encountered in the Asian plume and occasionally in the North American plume. 

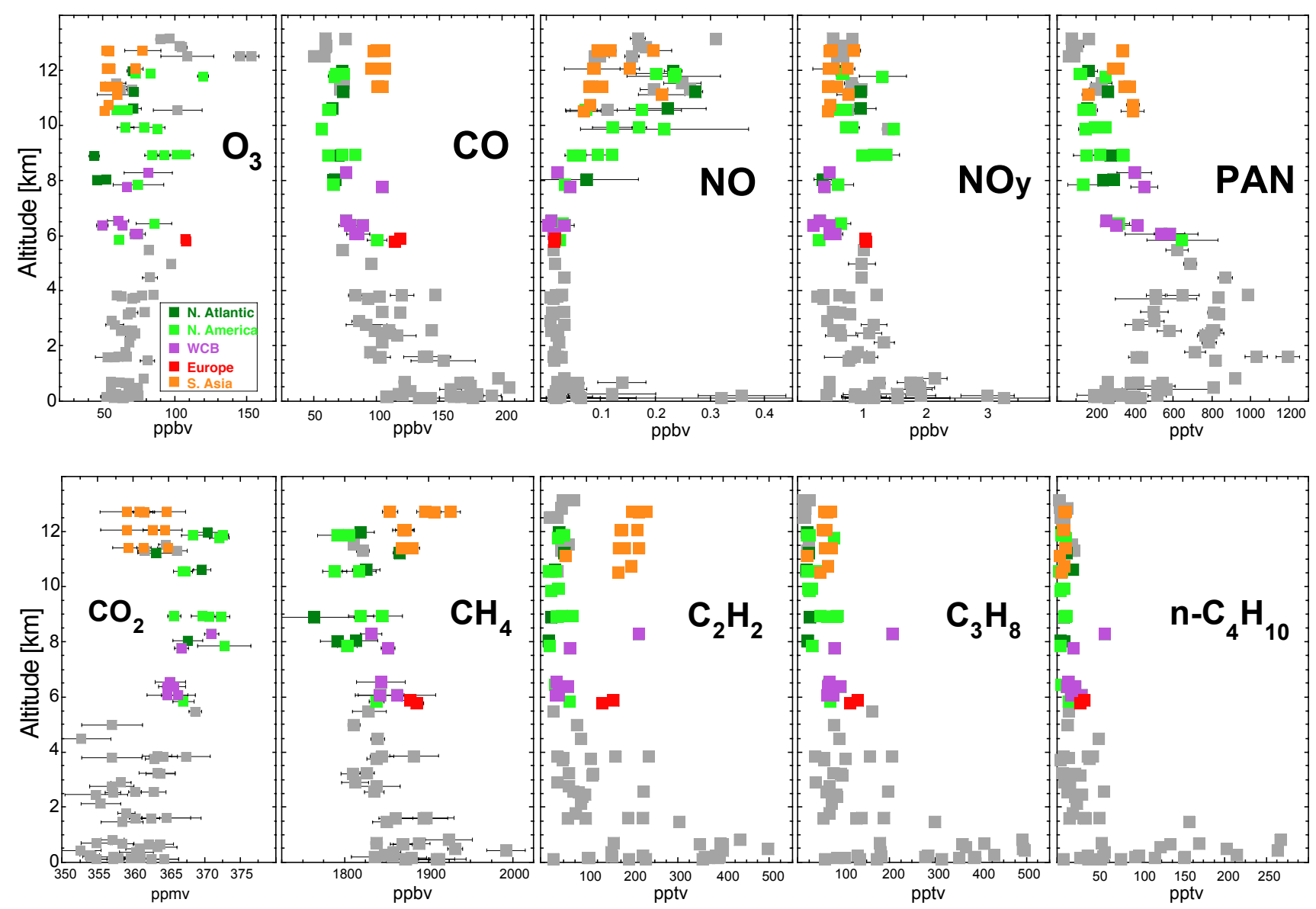

Fig. 2. Altitude profiles of gases measured between 3 and 22 August over the eastern Mediterranean. The data points (other than $C_{2}-C_{6}$ $\mathrm{NMHC}$ ) correspond to the mean of $\sim 5 \mathrm{~min}$ in-situ measurements coinciding with the collection of an air samples (1-2 per flight level of $\sim 15 \mathrm{~min}$ ), while the error bars reflect the variability ( $\sigma \sigma$ standard deviation). Color coding denotes the air mass origin (light green: North America, dark green: North Atlantic, orange: South Asia, purple: WCB pollution transport from eastern North America, red: southern European pollution from deep convection).

Figure 2 shows that the lower atmosphere in the eastern Mediterranean region contained the highest concentrations of $\mathrm{CO}$, NMHC and oxidized organic species associated with pollutant emissions from Europe. $\mathrm{CO}_{2}$, however, shows somewhat lower concentrations in the boundary layer than aloft, which is related to enhanced uptake by the vegetation during summer (Strahan et al., 1998). Although largescale subsidence prevails during the Mediterranean summer, enhanced concentrations of reactive pollutant tracer species such as PAN, acetone, methanol, acetylene, propane and benzene were detected in the lower free troposphere up to $\sim 6 \mathrm{~km}$ altitude. Convective transport is the most probable mechanism for mixing of polluted boundary layer air to the free troposphere, partly associated with land-sea breezes and orographic effects (Millan et al., 1997). A pronounced layer of relatively fresh pollution was encountered on 3 August (flight 2) at an altitude of $6 \mathrm{~km}$ (depicted as red squares in Fig. 2). This pollution plume was most likely related to outflow from a band of convective clouds and associated thunderstorm activity, which occurred over western Turkey and the Black Sea upwind of the flight track 1-2 days prior to the flight. Figure 3 shows an AVHRR thermal infrared image (NOAA 16 satellite) of this convective system close to the flight track were the pollution was observed. In addition, this polluted layer has been reproduced in model simulations by Lawrence et al. (2003) and Good et al. (2003), pointing to a well mixed plume of a few days old of regional origin.

Above $\sim 6 \mathrm{~km}$ altitude, long-range transport of pollution from outside Europe to the region appears to determine the vertical tracer concentration gradients. Between 6 and $9 \mathrm{~km}$ westerlies carry pollution from the North American continent to the region, mainly associated with the warm conveyor belt in synoptic disturbances (e.g. Cooper et al., 2001). As such, moist air containing pollution from the North American east coast can reach Europe in 3 to 5 days as shown by Stohl and Trickl (1999). Air masses associated with North American 

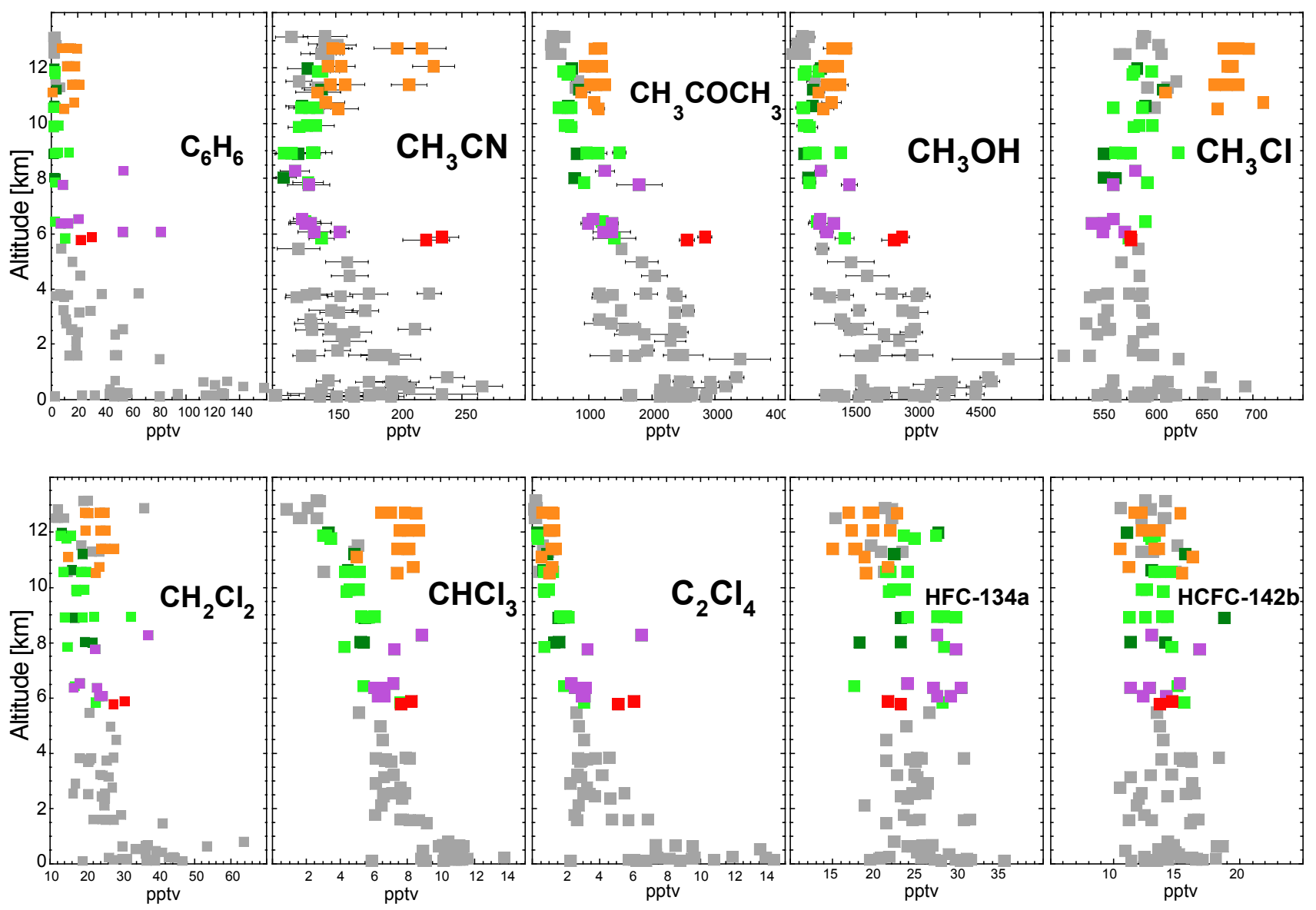

Fig. 2. Continued.

pollution (purple squares) contained relatively high benzene concentrations, probably related to traffic emissions, as well as high concentrations of the air-conditioning agent HCFC134a (discussed further in Sect. 4.2.4). An example of rapid uplifting of polluted air partly originating over the southeastern United States is depicted by the back-trajectory in Fig. 4 (see also the purple trajectories in Fig. 1). The WCB is visible in the cloud band along the North American east coast taken from a GOES 8 infrared satellite image (courtesy of METEOFRANCE) on 15 August 2001, at 12:00 UTC. The trajectories relate to a strongly polluted air mass encountered on 19 August 2001, at about $8 \mathrm{~km}$ altitude (360 hPa) containing high NMHC (notably benzene and propane), halocarbons as well as high ozone $(\sim 80 \mathrm{ppbv})$ most likely resulting from photochemical production. Higher in the upper troposphere at $10-13 \mathrm{~km}$, the South Asian plume (denoted by the orange squares in Fig. 2) is associated with a strong signature of biomass burning, i.e. enhanced concentrations of $\mathrm{CO}$, acetylene, benzene, acetone, acetonitrile, methyl chloride, and chloroform. This relates to the extensive use of biofuels in Asia, consistent with INDOEX measurements over the Indian Ocean (e.g. Lelieveld et al., 2001; de Gouw et al., 2001; Scheeren et al., 2002).

\subsection{Longitudinal tracer gradients in the upper troposphere}

Complementary to the vertical gradients in Fig. 2, Fig. 5 shows observed upper tropospheric concentrations of several trace species (between 6 and $13 \mathrm{~km}$ ) as a function of longitude of origin. The latter is deduced from the 10-day backtrajectory analysis. For this we applied the geographical endpoint of the 10-day backward trajectories, which appeared to be representative of the travel distance and position of an air parcel between 7 to 10 days back in time. In addition, 7 to 10 days agree well with the travel times of pollution from the major source regions to Mediterranean as indicated by the trajectories. We note that the latitudinal variability of the air mass origins varied between $20^{\circ}$ and $50^{\circ} \mathrm{N}$ for the Westerlies and between $5^{\circ}$ and $40^{\circ} \mathrm{N}$ for the easterlies. An analysis of latitudinal gradients showed no significant relationships and is therefore not shown here.

We applied a least squares linear fit on the data to illustrate the significance of the gradient (when present). Air masses with a recent stratospheric input (blue squares) were excluded from the linear fit $(\mathrm{PV}>3.0$ along the 10-days back trajectory in combination with observed ozone exceeding $90 \mathrm{ppbv})$, because we are interested in the tropospheric origin 


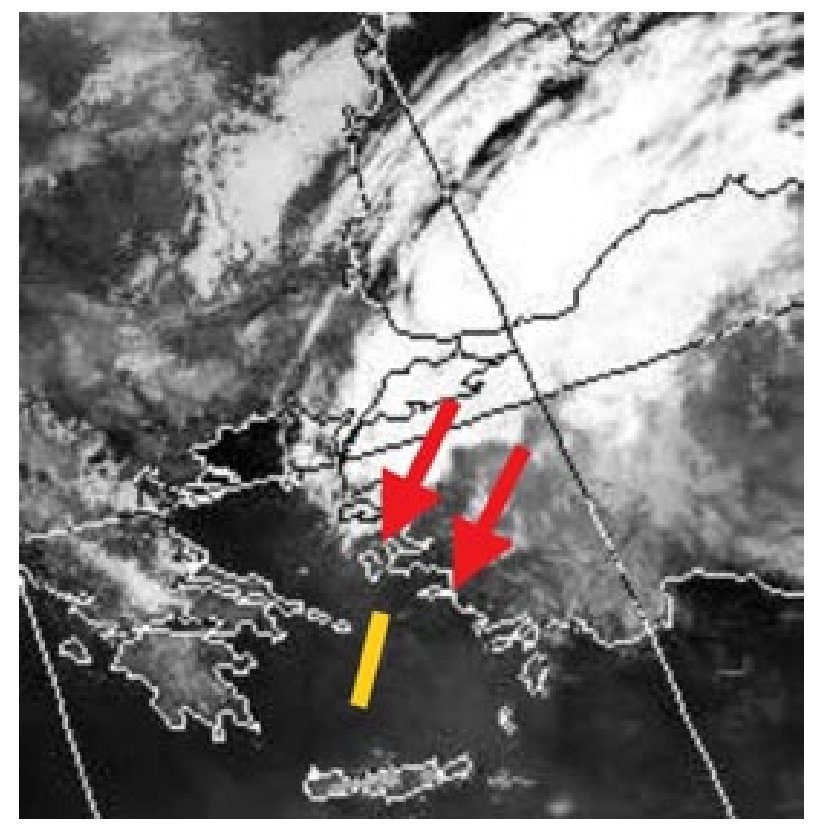

Fig. 3. Satellite image (NOAA 16 AVHRR thermal IR channel) taken on 2 August 2001, at 01:11 UTC showing a thick cloud band over northern Turkey and the black sea. The yellow line resembles the flight track at $6 \mathrm{~km}$ altitude, whereas the red arrows denote the general flow direction at that altitude.

of the species. Air masses that could be related to pollution lifted-up from the North American east coast (WCB) and advected across the Atlantic to Europe (based on the purple trajectories in Fig. 1) are marked as purple squares.

\subsection{1 $\mathrm{O}_{3}, \mathrm{CO}, \mathrm{NO}_{\mathrm{y}}$ and $\mathrm{NMHC}$}

The longitudinal gradients and mean values (Table 1) show that $\mathrm{O}_{3}, \mathrm{NO}$ and $\mathrm{NO}_{\mathrm{y}}$ concentrations were generally lower in the Asian plume than in the westerly air masses, while PAR $\left(\mathrm{C}_{2}-\mathrm{C}_{5}\right.$ alkanes or paraffin's) and $\mathrm{CO}$ were similar or higher. This points to $\mathrm{NO}_{\mathrm{x}}$-limited conditions for photochemical $\mathrm{O}_{3}$ production in the Asian plume and therefore a suppressed $\mathrm{OH}$ regeneration by NO (Lelieveld et al., 2001). The ratio of anthropogenic $\mathrm{NO}_{\mathrm{x}}$ emissions to the total $\mathrm{CO}$ and hydrocarbon emissions is estimated to be smaller for Asia than for Europe and North America (Olivier et al., 1996), which is associated with less efficient combustion processes. In addition, the lifetime of $\mathrm{NO}_{\mathrm{x}}$ in the tropical boundary layer is very short ( $<1$ day) due to efficient reaction to $\mathrm{HNO}_{3}$ and subsequent removal through wet and dry deposition (Lelieveld and Dentener, 2000). The lower $\mathrm{NO}_{\mathrm{y}}$ in the Asian plume may be partly related to the efficient removal of $\mathrm{HNO}_{3}$ in deep convection in the ASM.

Furthermore, the role of lightning produced $\mathrm{NO}_{\mathrm{x}}$, which provides a fresh source of $\mathrm{NO}_{\mathrm{x}}$ in the free troposphere, where the lifetime of $\mathrm{NO}_{\mathrm{x}}$ is longer (up to about a 1 week), is still poorly understood. In particular over the North Atlantic the lightning fraction of $\mathrm{NO}_{\mathrm{x}}$ in the westerlies might be relatively large (Jeker et al., 2000). Relatively high CO and PAR in the westerlies originated from the North American east coast and are associated with WCB transport (purple squares). The influence of stratosphere-to-troposphere transport, shown as blue squares in Fig. 5, is absent in the Asian plume but increases significantly towards more westerly air mass origins. In these air parcels ozone is significantly enhanced, while concentrations of $\mathrm{CO}$, higher hydrocarbon and oxidized organic tracer species are lower. This strongly influences the observed longitudinal trend of $\mathrm{CO}$ and $\mathrm{O}_{3}$. The longitudinal gradients of $\mathrm{O}_{3}, \mathrm{CO}, \mathrm{NO}_{\mathrm{y}}$ and $\mathrm{NMHC}$ are further investigated in Sect. 5 using the ECHAM 4 general circulation model.

\subsubsection{Methanol and acetone}

Both methanol and acetone depict a negative east-west trend as function of longitude. The main terrestrial sources of atmospheric methanol are plant emissions, and to a lesser extent emissions from plant decay, industrial production and biomass burning, making it an abundant organic species in the background atmosphere (Galbally and Kirstine, 2002). The chemical lifetime of methanol in the free troposphere based on reaction with $\mathrm{OH}$ is of the order of 2 weeks (Singh et al., 1995), suggesting that the mean age of the plumes we encountered is shorter than that. The release of methanol from biomass burning is typically associated with oxygen deficient smoldering fires, e.g. in the domestic and small industrial use of biomass fuel in Asia (Scheeren et al., 2002), resulting in an enhancement in the Asian plume. Similar to methanol, acetone has large natural sources (vegetation and oceans), is emitted by biomass burning but it is also formed in the atmosphere by hydrocarbon oxidation (Singh et al., 1995; Jacob et al., 2002). The chemical lifetime of acetone in the free troposphere as determined by photolysis and reaction with $\mathrm{OH}$ is of the order of 10-15 days, which is close to the chemical age of the upper tropospheric plumes. Nevertheless, the acetone concentration in the Asian and North American plumes of about 1 ppbv significantly exceeded the $\sim 0.5$ ppbv representative of the background upper troposphere (Jacob et al., 2002). Acetone and methanol correlated well $(r \geq 0.7)$ with $\mathrm{CO}$ and total $\mathrm{C}_{2}-\mathrm{C}_{7} \mathrm{NMHC}$ in the upper troposphere, shown in Fig. 6, suggesting that primary combustion sources and in situ photochemical production explain the general enhancement above background levels. Holzinger et al. (personal communication) analyzed the biomass burning influence on acetone, methanol, $\mathrm{CO}$ and PAN over the eastern Mediterranean during MINOS. They found strong indications of secondary photochemical production of acetone and methanol, in agreement with our analyses. Relatively high concentrations of $\sim 2.5$ ppbv of acetone and methanol in the free troposphere have been observed in fresh pollution on 2 August at $6 \mathrm{~km}$ altitude, most probably related to convection over northern Turkey (Fig. 3), described in Sect. 4.1. 

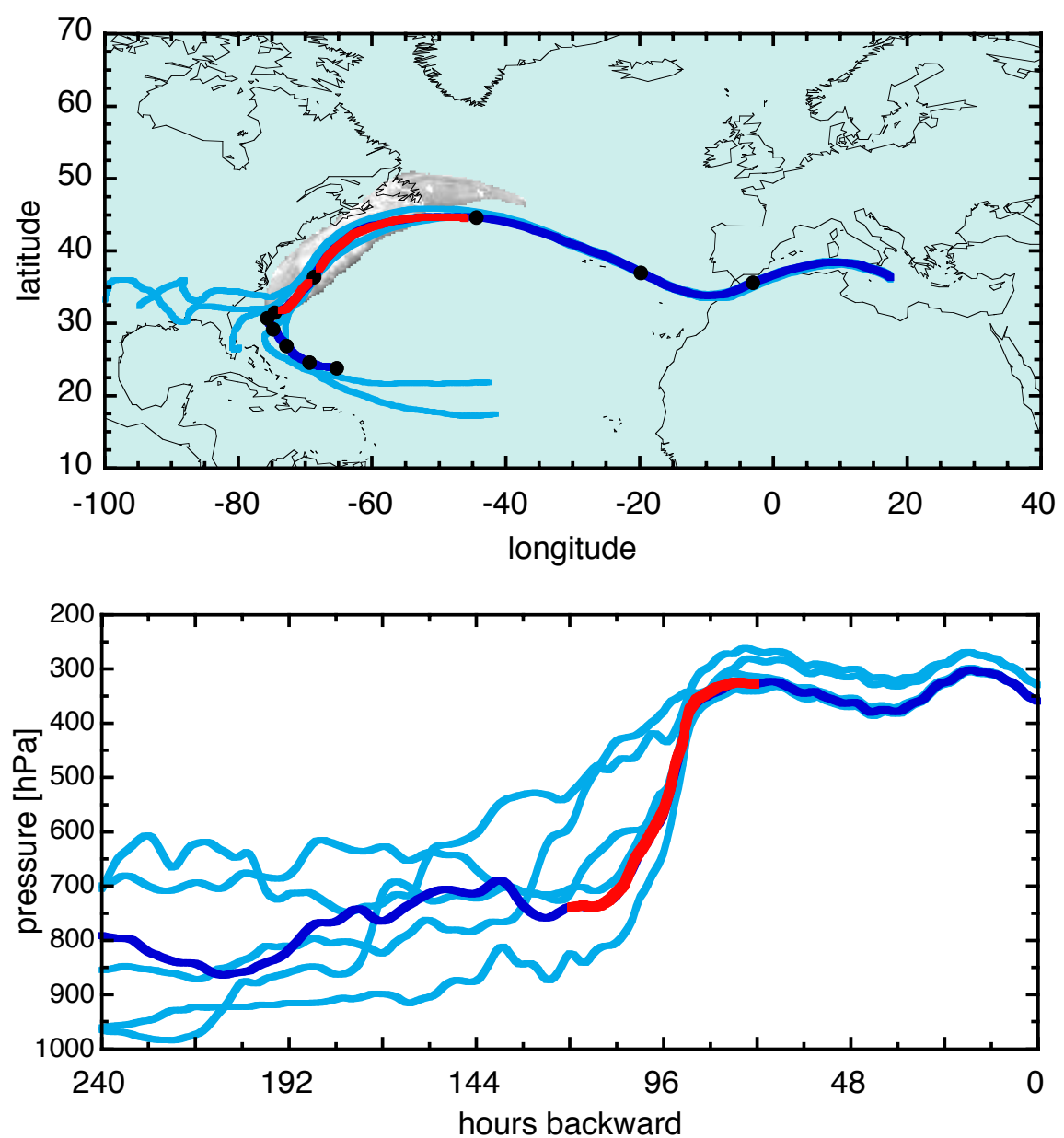

Fig. 4. Backward trajectories showing rapid uplifting of boundary layer air along the North American east coast 4 to 5 days prior to the flight on 19 August 2001. The dark blue trajectory relates to the polluted air mass detected at $360 \mathrm{hPa}, 17.6^{\circ} \mathrm{E}$ and $36.6^{\circ} \mathrm{W}$. The additional light blue trajectories, ending near the polluted air mass (at 360 to $330 \mathrm{hPa}, 17.6^{\circ} \mathrm{E}$ and $30.0-36.6^{\circ} \mathrm{W}$ ), indicate the possible air mass origins with emphasis on the southeastern United States. The superimposed cloud band along the North American east coast was taken from an infrared satellite image (GOES 8) on 15 August 2001, at 12:00 UTC associated with the WCB.

\subsection{3 $\mathrm{CH}_{4}$ and $\mathrm{CH}_{3} \mathrm{Cl}$}

Both $\mathrm{CH}_{4}$ and $\mathrm{CH}_{3} \mathrm{Cl}$ are enhanced in the Asian plume, resulting in a negative longitudinal east-west gradient. Methane may be enhanced in the northern mid-latitude boundary layer (relative to a mid-latitude Northern Hemispheric background of $\sim 1800 \mathrm{ppbv}$ from AGAGE, Prinn et al., 2000) from the production and use of natural gas (see Fig. 2), while enhancements in tropical air masses most likely relate to emissions from rice paddies and natural wetlands (Houweling et al., 2000). Methyl chloride has strong terrestrial (vegetation and soils) and oceanic sources (Yokouchi et al., 2001; Lee-Taylor et al., 2001) contributing to the global background of $\sim 550 \mathrm{pptv}$. An additional large source in South Asia is biofuel burning (Scheeren et al., 2002), leading to the large enhancement observed in the Asian plume. During the northern mid-latitude summer emissions from natural forest fires at mid-latitudes could also play a role, as can be deduced from the average concentration of $576 \pm 19$ pptv (median of 578 pptv), which is somewhat higher than the $\mathrm{CH}_{3} \mathrm{Cl}$ background.

\subsubsection{HFC-134a, HCFC-141b and HCFC-142b}

The relatively new fluorocarbon HFC-134a (in use since 1990) shows a consistently lower concentration in the Asian plume (19 \pm 2 pptv) compared to westerly air masses $(25 \pm 3)$. Highest concentrations were detected in the European boundary layer $(27 \pm 5)$ and in air masses associated with WCB transport from the North American east coast $(29 \pm 1)$. At present, HFC-134a is mainly used as cooling agent in automobile air-conditioning systems as a replacement of CFC-11 (AFEAS, 2002). Mobile air conditioning is considered as one of the major sources of fluorocarbons 

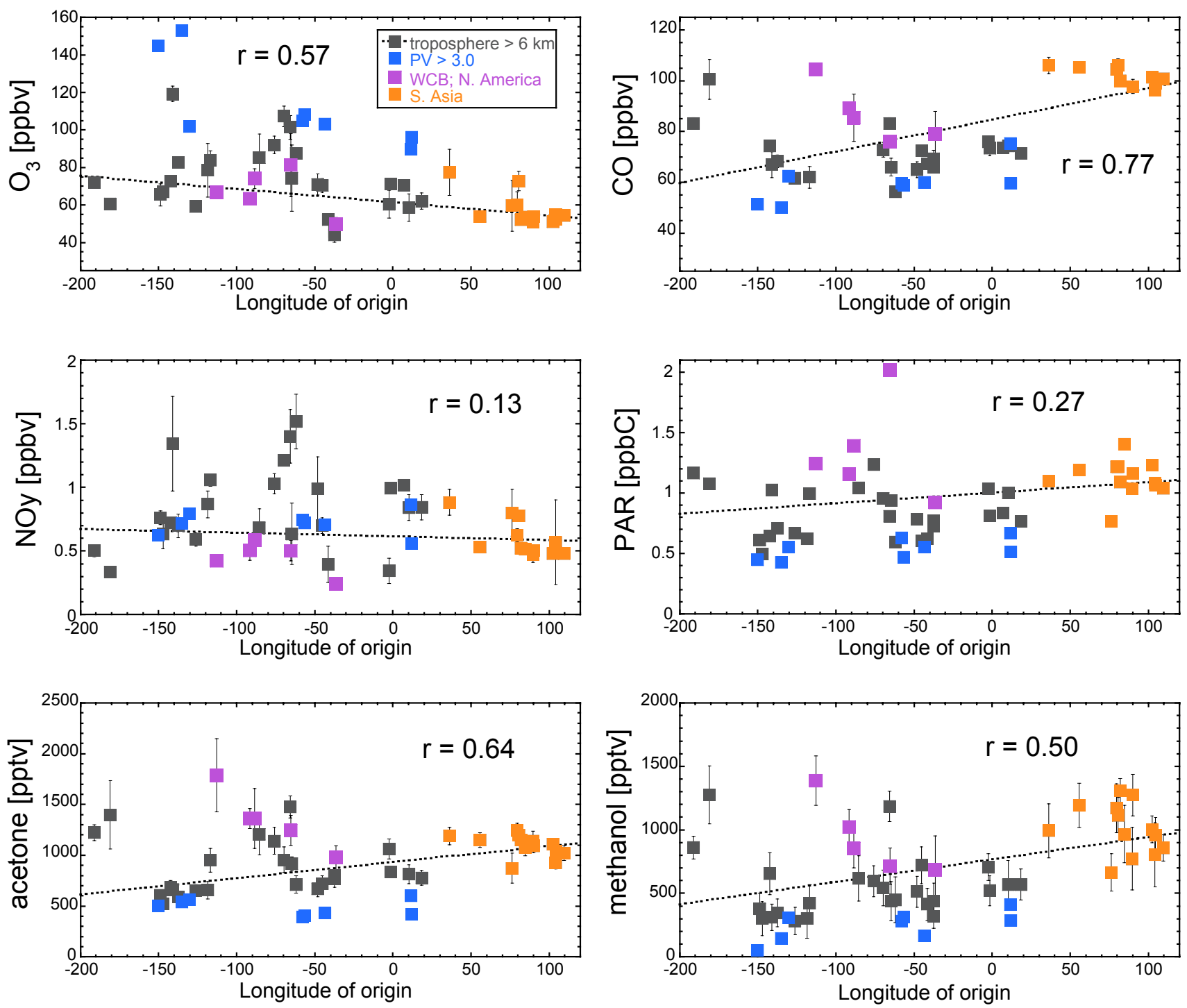

Fig. 5. Longitudinal gradients of selected gaseous tracer species in the upper troposphere between 6 and $13 \mathrm{~km}$ altitude). The longitude of origin (air mass origin) for each data point is deduced from 10-day backward trajectory analysis (presented in Fig. 1). The data points (other than $\mathrm{C}_{2}-\mathrm{C}_{5}$ alkanes or paraffin's (PAR)) correspond to the mean of $\sim 5 \mathrm{~min}$ in-situ measurements coinciding with the collection of air samples (1-2 per flight level of $\sim 15 \mathrm{~min}$ ). The error bars denote the measured variability of the selected data (1 $\sigma$ standard deviation). Color coding relates to specific air mass characteristics (blue: stratospheric history along the trajectory, purple: WCB transport from eastern North America, orange: Southern Asia).

with annual leakage rates up to $10 \%$ per year (EIA, 2002). Emissions of HFC-134a are concentrated in the US and Europe with vehicle numbers of about 200 million each in the year 2000, whereas the number of registered vehicles in India and China is presently of the order of $\sim 20$ million (WRI, 2002). It is estimated that presently $\sim 35 \%$ of European and $\sim 90 \%$ of all American motor vehicles are equipped with air-conditioning. The HFC-134a chemical lifetime of $\sim 14$ years (Kanakidou et al., 1995) has caused an accumulation of HFC-134a to its present background level of $\sim 20 \mathrm{pptv}$. HFC-134a can serve as a tracer for western pollution, so that enhanced concentrations suggest North American or European pollution. The chlorofluorocarbons HCFC-142b and HCFC-141b, not shown in Fig. 5, are mainly used as industrial solvents and for long-life applications as a blowing agent for closed-cell foams (in use since 1981 and 1990, respectively (AFEAS, 2002)). Emissions of HCFC-141b and HCFC-142b to the atmosphere are therefore smaller than of HFC-134a and not so wide-spread, while their chemical lifetimes are similar $(\sim 10$ and $\sim 20$ years, respectively (Kanakidou et al., 1995)), explaining their lower atmospheric variability (see Table 1). 

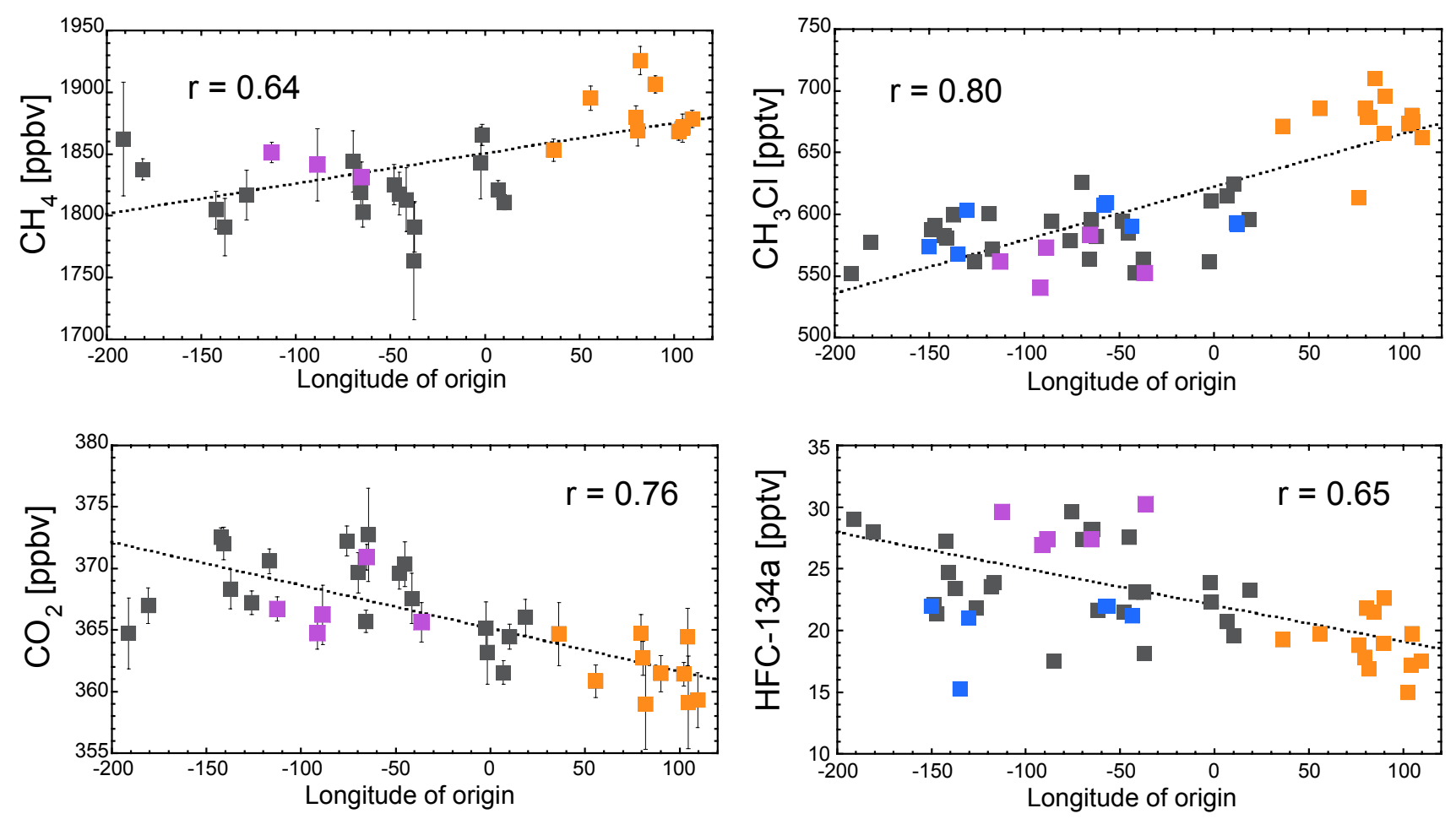

Fig. 5. Continued.

\subsection{5 $\quad \mathrm{CO}_{2}$}

The longitudinal gradient of $\mathrm{CO}_{2}$ shows a strong positive tendency from east to west. Model and measurement based studies have shown that the seasonality of $\mathrm{CO}_{2}$ at the surface has a larger amplitude in the extra-tropics than in the tropics (Strahan et al., 1998; Matsueda et al., 2002). Therefore, during summer $\mathrm{CO}_{2}$ concentrations are lower at high latitudes. In the upper troposphere, however, the $\mathrm{CO}_{2}$ seasonal cycle is less pronounced and has approximately the same amplitude and phase in both the extra-tropics and the tropics (Strahan et al., 1998). This would not lead to the observed longitudinal $\mathrm{CO}_{2}$ gradient, which points to pollution sources in the westerlies. Upper tropospheric $\mathrm{CO}_{2}$ concentrations have been correlated with concurrent $\mathrm{HFC}-134 \mathrm{a}, \mathrm{CH}_{4}, \mathrm{CH}_{3} \mathrm{Cl}$ and $\mathrm{CH}_{3} \mathrm{CN}$ to investigate possible sources, presented in Fig. 7 . We find a significant positive correlation between $\mathrm{CO}_{2}$ and HFC-134a (at the 95\% significance level), a tracer for pollution from North American continent, and a negative correlation between $\mathrm{CO}_{2}$ and $\mathrm{CH}_{4}$, and the biomass burnings tracers $\mathrm{CH}_{3} \mathrm{Cl}$ and $\mathrm{CH}_{3} \mathrm{CN}$. Our measurements thus indicate that pollution originating from the North American east coast is enriched in $\mathrm{CO}_{2}$, most likely from fossil fuel burning.

\subsection{Chemical age of the Asian plume}

The age of the Asian pollution detected in the upper troposphere refers to the travel time of pollutant species away from

their sources. We estimate the air mass age from the enhancement or emission ratio (ER) of biomass burning species with different photochemical lifetimes relative to $\mathrm{CO}$, that will change as function of travel time. The ER of species $X$ can be determined as the slope of a linear regression fit $(\Delta \mathrm{X} / \Delta \mathrm{CO})$. We focus on typical biomass burning species methyl chloride, acetonitrile, acetylene and benzene that are chemically removed by the $\mathrm{OH}$ radical only. We compared ER's from MINOS measurements $\left(E R_{t}\right)$ in the Asian plume with ER's from INDOEX 1999 measurements obtained over the Indian Ocean reported by de Gouw et al. (2001) and Scheeren et al. (2002), which we consider as source ER's $\left(E_{0}\right)$. The INDOEX $\mathrm{ER}_{0}$ are typical for pollution from the Indian continent, which is considered as one of the main source regions for the Asian plume pollution, dominated by emissions from the industrial and residential use of biofuels. The MINOS ER's $\left(E_{t}\right)$ were taken as the slope from a linear regression fit performed on the hydrocarbon to $\mathrm{CO}$ relationship in the Asian plume, depicted in Fig. 8. Depending on the reactivity of the species relative to $\mathrm{CO}$, the source ratio $\mathrm{ER}_{0}$ changes as a function of transport time or chemical age $\Delta t$ and the mean $\mathrm{OH}$ radical concentration. The relationship between the $\mathrm{ER}_{0}$ and the $\mathrm{ER}_{\mathrm{t}}$ can be described by:

$\mathrm{ER}_{0}=\mathrm{ER}_{\mathrm{t}} / \mathrm{e}^{\left(\mathrm{k}_{\mathrm{CO}}-\mathrm{ks}_{\mathrm{s}}\right)[\mathrm{OH}] \Delta \mathrm{t}}$

where $\mathrm{k}_{\mathrm{CO}}$ and $\mathrm{k}_{\mathrm{S}}$ are the $\mathrm{OH}$ reaction rate coefficients for $\mathrm{CO}$ and emission species $\mathrm{S}$ taken from Atkinson et al. 

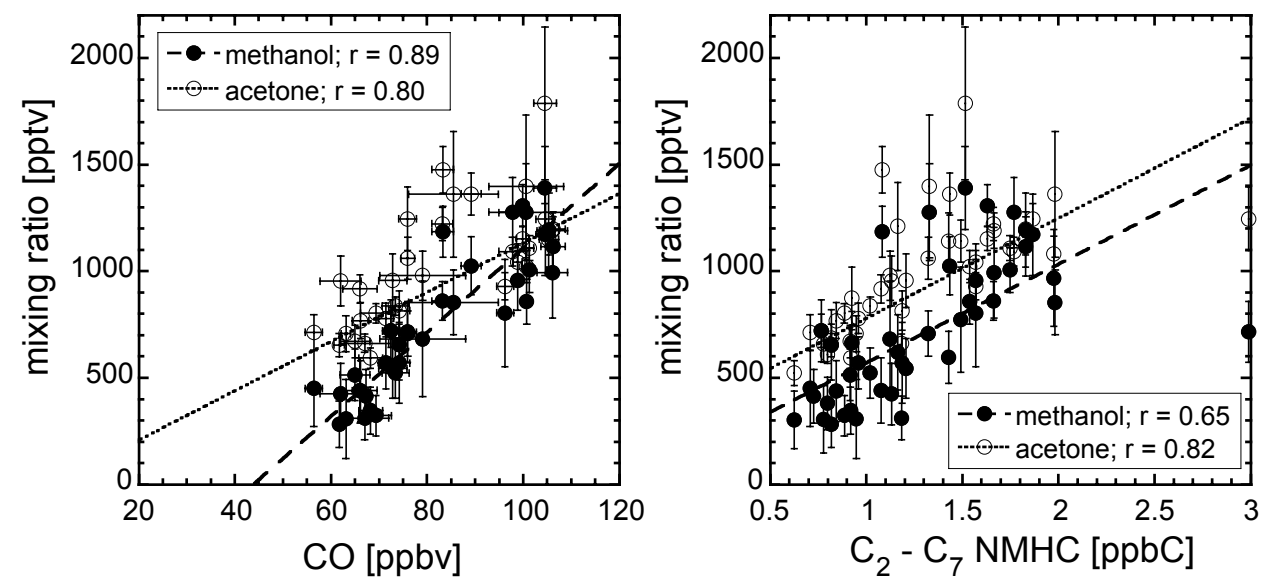

Fig. 6. Correlation of methanol and acetone with $\mathrm{CO}$ and $\mathrm{C}_{2}-\mathrm{C}_{7}$ NMHC in the free troposphere (>6 km) during MINOS (r at the $95 \%$ significance level). The error bars show the $1 \sigma$ standard deviation of the data points.
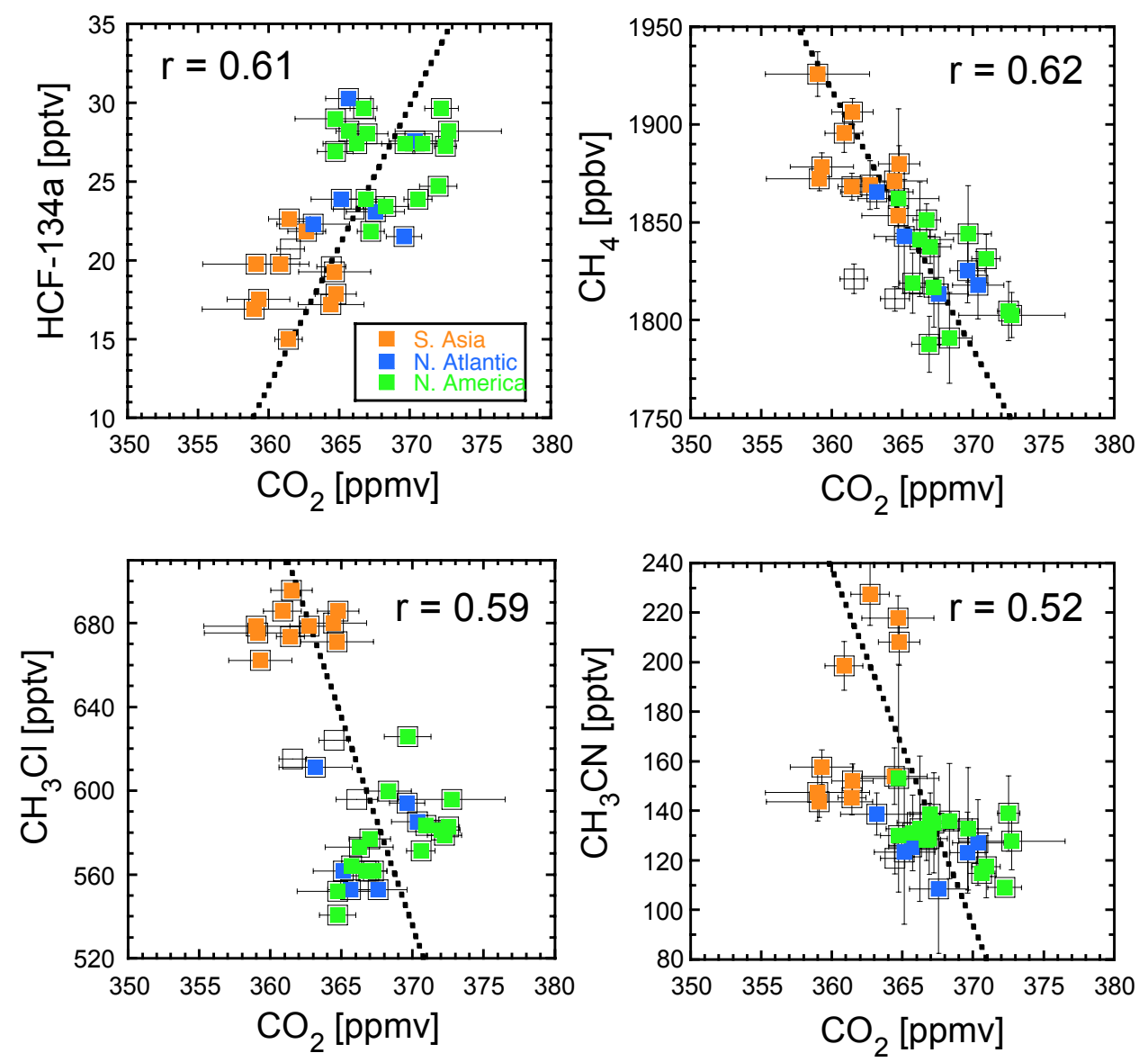

Fig. 7. Correlation of HCF-134a (North American pollution tracer), $\mathrm{CH}_{4}$ (tropical air mass tracer), $\mathrm{CH}_{3} \mathrm{Cl}_{\text {and }} \mathrm{CH}_{3} \mathrm{CN}$ (biomass burning tracers) with $\mathrm{CO}_{2}$ ( $\mathrm{r}$ at the $95 \%$ significance level) in the upper troposphere ( $>6 \mathrm{~km}$ ). Orange dots relate to a South Asian origin, blue to the (sub-tropical) northern Atlantic, and green to North America. The error bars denote the measured variability of the data points $(1 \sigma$ standard deviation). 

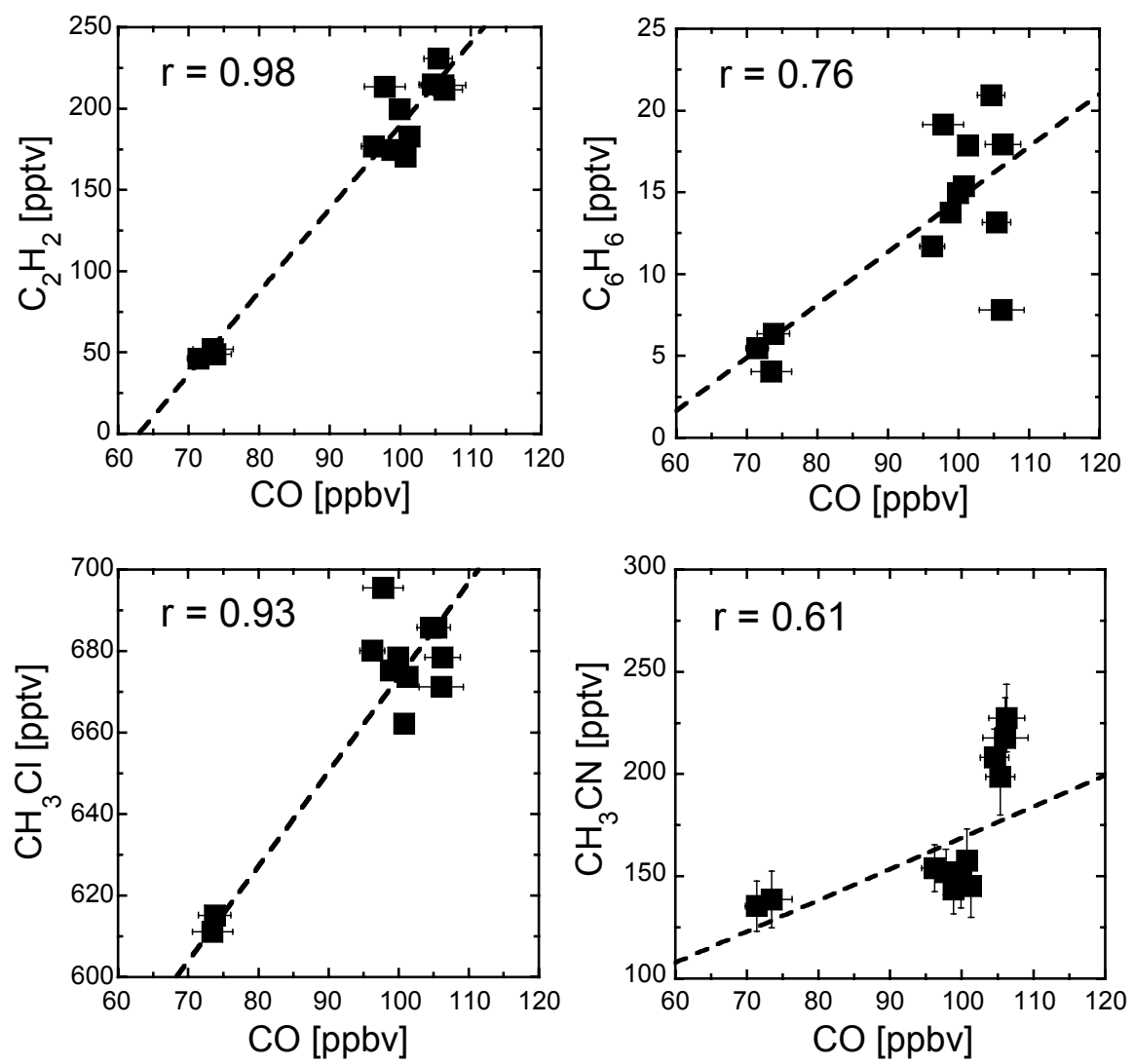

Fig. 8. Correlations of selected biomass burning tracers with CO in the South Asian plume. Linear regression ( $\mathrm{r}$ at the $95 \%$ confidence level) provided biomass burning Emission Ratios (ER) relative to CO. Error bars denote the measured variability ( $\sigma \sigma$ standard deviation).

(1997), respectively, $(\mathrm{OH})$ is the diurnal mean $\mathrm{OH}$ radical concentration in molecules $\mathrm{cm}^{-3}$. The chemical age $\Delta \mathrm{t}$ can be determined from Eq. (1).

We assumed mean temperature and pressure conditions of $235 \mathrm{~K}$ and $225 \mathrm{hPa}$ measured in the Asian plume and a daily mean $\mathrm{OH}$ concentration of $1.0 \pm 0.2 \times 10^{6}$ molecules $\mathrm{cm}^{-3}$ taken from the ECHAM4 general circulation model (described in more detail in Sect. 5) for 6 to $12 \mathrm{~km}$ altitude. Using Eq. (1), we derived a best match of the MINOS ER, apart from acetylene, with the INDOEX $\mathrm{ER}_{0}$ values at a $\Delta \mathrm{t}$ of about 13 days presented in Table 2. The low acetylene ER from INDOEX might be related to additional breakdown away from combustion sources in the Asian boundary layer prior to deep convection into the upper troposphere. A better agreement is found with the mean biomass burning ER of $8 \pm 4 \mathrm{pptv} \mathrm{ppbv}^{-1}$ for acetylene found in fresh biomass burning emissions from various studies reported by Veldt and Berdowski (1995).

Based on the back trajectory analysis (shown in Fig. 1), the transport times from South Asia towards the Mediterranean are 5-10 days in the upper troposphere. Traub et al. (2003) present 20-day forward trajectories with starting points in two West Indian cities (Madras, $80.76^{\circ} \mathrm{E} / 13.85^{\circ} \mathrm{N}$; Patna, $85.72^{\circ} \mathrm{E} / 26.01^{\circ} \mathrm{N}$ ) for July 2001 , indicating travel times of 2-5 days for deep convection from the boundary layer to the upper troposphere over India. Hence, combining these back and forward trajectories, we can deduce travel times from the Asian boundary layer to the Mediterranean upper troposphere ranging from 7 to 15 days. In spite uncertainties involved in estimating the chemical age (Jobson et al., 1998), the chemical age of the encountered pollution in the Asian plume seems to be quite realistic and in agreement with trajectory analysis.

\section{Asian pollution observed in the lowermost strato- sphere}

Besides the global impact of the ASM dynamics, model studies indicate an important potential for pollution transport into the lower stratosphere (Chen, 1995; Dethof et al., 2000). Deep convection in the ITCZ (InterTropical Convergence Zone) over South Asia adds pollution to the upper tropospheric anti-cyclonic circulation. The associated upward motion pushes the subtropical tropopause to $\sim 16 \mathrm{~km}$ altitude over a relatively large region (Roelofs et al., 2003). The subtropical tropopause slopes down to about $11 \mathrm{~km}$ towards 

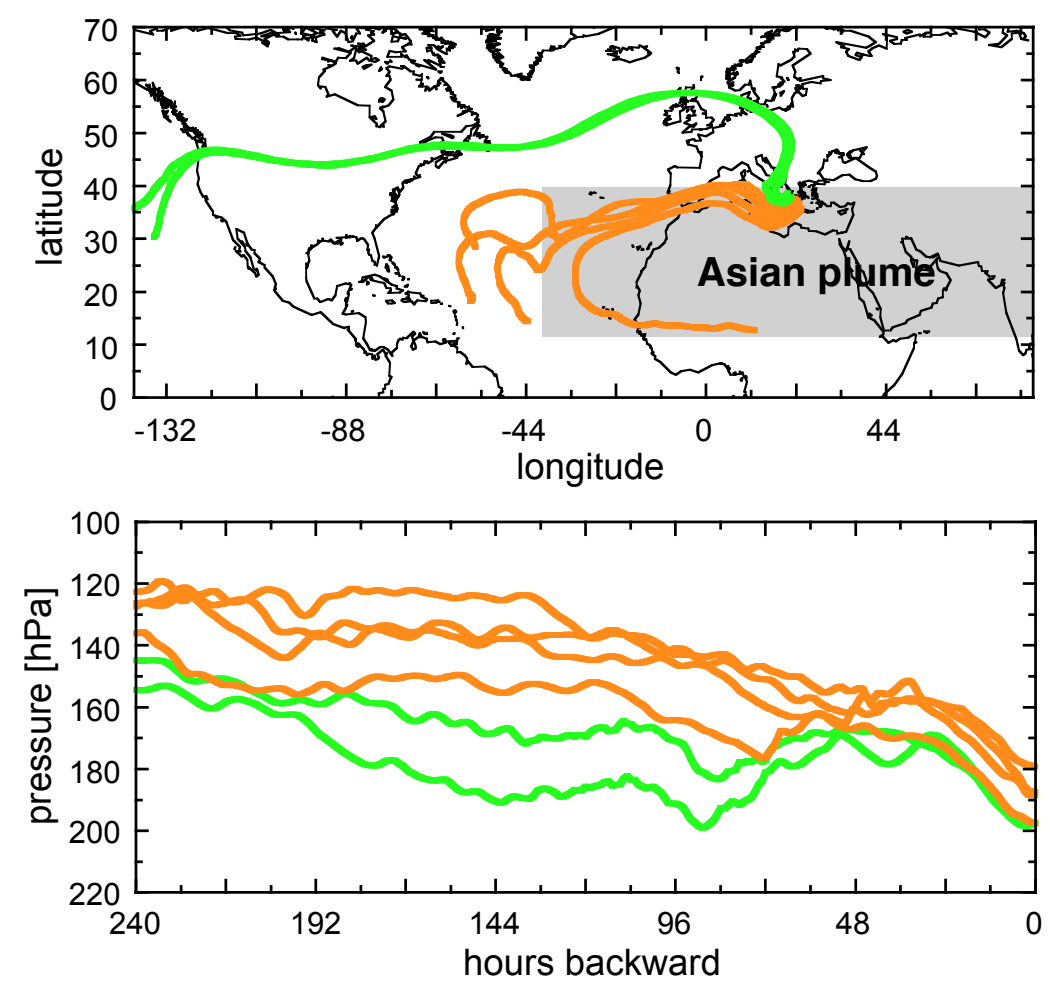

Fig. 9. Ten-day backward trajectories for air masses sampled in the tropopause/lower stratosphere region during 16 August (flight 8 ) over the eastern Mediterranean. The shaded area denotes the geographical range where the Asian plume affects atmospheric chemistry during August 2001, based on model simulations.

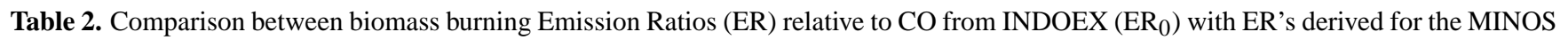
Asian plume $\left(E R_{t}\right)$. Standard deviation $(1 \sigma)$ of ER between parentheses. A best match is achieved when assuming a photochemical age of the Asian plume of $\sim 13$ days (at mean temperature and pressure of $235 \mathrm{~K}$ and $225 \mathrm{hPa}$ measured in the Asian plume and a diurnal mean $\mathrm{OH}$ concentration of $\sim 1 \times 10^{6}$ molecules $\mathrm{cm}^{-3}$ estimated by the ECHAM model for 6-12 $\mathrm{km}$ altitude)

\begin{tabular}{|c|c|c|c|c|c|}
\hline \multirow[t]{2}{*}{ Emission species } & \multirow{2}{*}{$\begin{array}{l}\mathrm{ER}_{0} \\
\text { pptv ppbv }{ }^{-1}\end{array}$} & \multirow{2}{*}{$\begin{array}{l}\text { MINOS ER } R_{t} \\
\text { pptv ppbv }{ }^{-1}\end{array}$} & \multicolumn{3}{|c|}{ MINOS ER $\mathrm{R}_{\mathrm{t}}$ at } \\
\hline & & & -5 days & -10 days & -13 days \\
\hline $\mathrm{CH}_{3} \mathrm{CN}^{\mathrm{a}}$ & $1.1(0.4)$ & $1.5(0.3)$ & 1.44 & 1.36 & 1.31 \\
\hline $\mathrm{CH}_{3} \mathrm{Cl}^{b}$ & $1.98(0.24)$ & $2.32(0.28)$ & 2.17 & 2.05 & 1.98 \\
\hline $\mathrm{C}_{2} \mathrm{H}_{2}{ }^{a}$ & $3.3(0.2)$ & $5.1(0.3)$ & 5.9 & 6.8 & 7.4 \\
\hline $\mathrm{C}_{6} \mathrm{H}_{6}{ }^{a}$ & $0.95(0.05)$ & $0.32(0.08)$ & 0.48 & 0.72 & 0.92 \\
\hline
\end{tabular}

${ }^{a}$ de Gouw et al. (2001)

${ }^{\text {b}}$ Scheeren et al. (2002)

higher latitudes, providing favorable conditions for isentropic cross-tropopause transport. The potential impact of the Asian plume for pollution transport into the lower stratosphere is large because of its high pollution level, large scale and its persistent presence between June and September.

The tropopause over the MINOS measurement area was generally located above the maximum flight altitude of the Falcon aircraft of $\sim 13 \mathrm{~km}$. Fortunately, on 16 and $17 \mathrm{Au}-$ gust, a trough located north of Crete lowered the tropopause to about $10-11 \mathrm{~km}$ altitude providing an opportunity to sam- ple the upper tropopause/lower stratosphere over the region. Hence, on 16 August (flight 8) the aircraft first crossed the tropopause at about $10.5 \mathrm{~km}$ altitude measuring ozone values of $\sim 100 \mathrm{ppbv}$. It then climbed to about $12.5 \mathrm{~km}$ and traversed the trough again observing ozone values $>150 \mathrm{ppbv}$. Six air samples were collected in the trough and the air mass origin was analyzed with 10-day backward trajectories depicted in Fig. 9. It shows that air masses with a westerly component (green) converged with air masses with an easterly component (orange), coming from the (shaded) 
Table 3. Indications of Asian pollution observed in the upper tropopause/lower stratosphere region (PV >3.0) on 16 August 2002 over the eastern Mediterranean at an altitude of $10.5-12.8 \mathrm{~km}$. Shown are mean values and $1 \sigma$ standard deviation

\begin{tabular}{|c|c|c|c|c|c|c|c|}
\hline $\begin{array}{l}\text { Air mass } \\
\text { origin }\end{array}$ & $\begin{array}{l}\text { PV } \\
\text { PV-units }\end{array}$ & $\begin{array}{l}\mathrm{O}_{3} \\
\mathrm{ppbv}\end{array}$ & $\begin{array}{l}\text { CO } \\
\text { ppbv }\end{array}$ & $\begin{array}{l}\text { NMHC } \\
\text { ppbC }\end{array}$ & $\begin{array}{l}\mathrm{CH}_{3} \mathrm{Cl} \\
\text { pptv }\end{array}$ & $\begin{array}{l}\text { Acetone } \\
\text { pptv }\end{array}$ & $\begin{array}{l}\text { Methanol } \\
\text { pptv }\end{array}$ \\
\hline Westerly & $3.8(0.2)$ & $149(6)$ & $51(1)$ & $0.54(0.02)$ & $571(4)$ & $522(65)$ & $100(128)$ \\
\hline Easterly & $3.2(0.6)$ & $103(5)$ & $60(1)$ & $0.71(0.07)$ & 600 (10) & $412(61)$ & 263 (126) \\
\hline
\end{tabular}

region affected by the Asian plume (northern Africa and the tropical North Atlantic). Measurements in the trough of $\mathrm{CO}, \mathrm{O}_{3}, \mathrm{NMHC}, \mathrm{CH}_{3} \mathrm{Cl}$, acetone and methanol, along with PV from the ECMWF analysis are presented in Table 3. We found enhanced concentrations of $\mathrm{CO}$, NMHC, $\mathrm{CH}_{3} \mathrm{Cl}$ and methanol in air masses with an easterly component, that closely resemble the chemical characteristics of the Asian plume in presented in Table 1 and Fig. 2. These results provide first indications that troposphere-to-stratosphere exchange of Asian pollution affects the lowermost stratosphere over the Mediterranean. Clearly, dedicated measurements and model work are needed to quantitatively asses TSE of Asian pollution associated with the ASM.

\section{Model simulations of the upper troposphere}

We used the ECHAM4 general circulation model (European Centre Hamburg Model version 4) to simulate observed gradients of $\mathrm{CO}, \mathrm{O}_{3}, \mathrm{NO}_{\mathrm{y}}$ and total carbon from the sum of $\mathrm{C}_{2}-\mathrm{C}_{5}$ alkanes (PAR) to help us better understand the characteristics of the upper troposphere during MINOS. The model has a T63 horizontal resolution of approximately $1.9^{\circ} \times 1.9^{\circ}$, a time step of $15 \mathrm{~min}$, and has 19 vertical levels up to $10 \mathrm{hPa}$ (the troposphere between 5 and $14 \mathrm{~km}$ consists of 6 model layers). The model has been initiated from January 2001 and uses analyzed ECMWF winds fields similar to the trajectory analysis. The model data are derived from spatial and temporal interpolation using the 3 hourly T63 model output, consistent with the sample date, mean time, and location (altitude, latitude and longitude) of the selected measurements points in the upper troposphere. For more details about the model we refer to Roelofs and Lelieveld (2000).

\subsection{Simulated longitudinal gradients of $\mathrm{O}_{3}, \mathrm{CO}, \mathrm{NO}_{\mathrm{y}}$ and NMHC}

Figure 10 shows the qualitative agreement between simulated and observed longitudinal gradients of $\mathrm{CO}, \mathrm{O}_{3}$, $\mathrm{NO}_{\mathrm{y}}$ and $\mathrm{C}_{2}-\mathrm{C}_{5}$ alkanes (parafines; PAR). For clarity, a weighted fit through the model output is shown, leaving out the individual data points. In addition, the mean model and measurement results for westerly air masses (North American and North Atlantic) and the Asian plume as well as the mean model to measurement ratio are presented in Table 4. The mean model to measurement ratio represents an attempt to compare model and measurements in a more quantitative way. Measured and modeled mean NO concentrations (not shown in Fig. 10) are also included in Table 4.

Looking at $\mathrm{CO}$ and $\mathrm{O}_{3}$ gradients, it appears that the general agreement between modeled and measured values in the upper troposphere is quite good, which is reflected in a mean model/measurements ratio close to 1 . A closer look shows that enhanced CO associated with WCB uplifting of North American pollution (purple dots) is not well reproduced by the model. Hydrocarbons $\left(\mathrm{C}_{2}-\mathrm{C}_{5}\right.$ alkanes) are reasonably well simulated in the Asian plume (mean model/measurement ratio of 1.3) but underestimated by factor of 2.4 in the westerly air masses. Here, the stratospheric influence appears to be overestimated while the contribution of North American pollution, including $\mathrm{CO}$, is underestimated. The ECHAM4 model tends to overestimate the role of downward tracer transport, notably of stratospheric ozone across the tropopause (Roelofs et al., 2003). In addition, the relatively coarse vertical resolution of the model allows more efficient mixing between shallow layers of pollution than might be realistic. For example, the WCB transports fresh North American pollution plumes to an altitude of 6 to $9 \mathrm{~km}$ across the Atlantic, which were typically encountered as distinct layers of a few hundreds of meters thick. As a result, modeled hydrocarbons (PAR) and CO can be underestimated, while the stratospheric influence is overestimated at the expense of photochemically produced ozone. Indeed, for the selected WCB data points the model/measurement ratio for $\mathrm{O}_{3}$ and PAR is 1.2 and 0.2 , respectively.

$\mathrm{NO}_{\mathrm{y}}$ is reasonably well simulated in the Asian plume, but misses most of the enhanced $\mathrm{NO}_{\mathrm{y}}$ concentrations observed in the westerlies. NO is underestimated by a factor of 3 in the Asian plume and by a factor of 1.8 in the westerlies (Table 4). The observed enhanced tropospheric $\mathrm{NO}_{\mathrm{y}}$ (and $\mathrm{NO}_{\mathrm{x}}$ ) values are most probably related to lightning produced $\mathrm{NO}_{\mathrm{x}}$ over the Atlantic, not well represented in the model. Recent observations of $\mathrm{NO}_{\mathrm{x}}$ in the tropopause region over the United States and the Northern Atlantic have shown that in-situ lightning production is as important as convective transport from the polluted boundary layer for the $\mathrm{NO}_{\mathrm{x}}$ budget during summer (Jeker et al., 2000; Brunner et al., 2001).

In summary, the Asian plume chemistry is reasonably well simulated by the model, whereas in the westerlies the influence of stratosphere-to-troposphere exchange tends to be overestimated, while the influence of North American pollution is underestimated. 
Table 4. Comparison between measurements (MINOS) and model simulations (ECHAM) for $\mathrm{O}_{3}, \mathrm{CO}, \mathrm{C}_{2}-\mathrm{C}_{5}$ alkanes (PAR) and $\mathrm{NO}_{\mathrm{y}}$ species. Mean concentrations (and $1 \sigma$ standard deviation) and the model/measurement ratios R are shown for the Asian plume and westerly air masses $>6 \mathrm{~km}$ altitude (includes North American and North Atlantic air masses)

\begin{tabular}{llllll}
\hline & $\mathrm{O}_{3} \mathrm{ppbv}$ & $\mathrm{CO} \mathrm{ppbv}$ & $\mathrm{PAR} \mathrm{ppbC}$ & NO pptv & NOy ppbv \\
\hline MINOS Asian plume & $57(8)$ & $102(4)$ & $1.12(0.15)$ & $0.11(0.05)$ & $0.59(0.14)$ \\
ECHAM Asian plume & $51(3)$ & $111(6)$ & $1.41(0.17)$ & $0.03(0.01)$ & $0.47(0.03)$ \\
MINOS westerlies & $73(18)$ & $74(12)$ & $0.91(0.32)$ & $0.11(0.08)$ & $0.76(0.34)$ \\
ECHAM westerlies & $76(17)$ & $73(7)$ & $0.34(0.14)$ & $0.04(0.02)$ & $0.49(0.06)$ \\
\hline R-Asia & $0.90(0.14)$ & $1.11(0.09)$ & $1.27(0.17)$ & $0.31(0.08)$ & $0.83(0.20)$ \\
R-westerlies & $1.10(0.34)$ & $1.01(0.18)$ & $0.42(0.24)$ & $0.57(0.44)$ & $0.79(0.44)$ \\
\hline
\end{tabular}
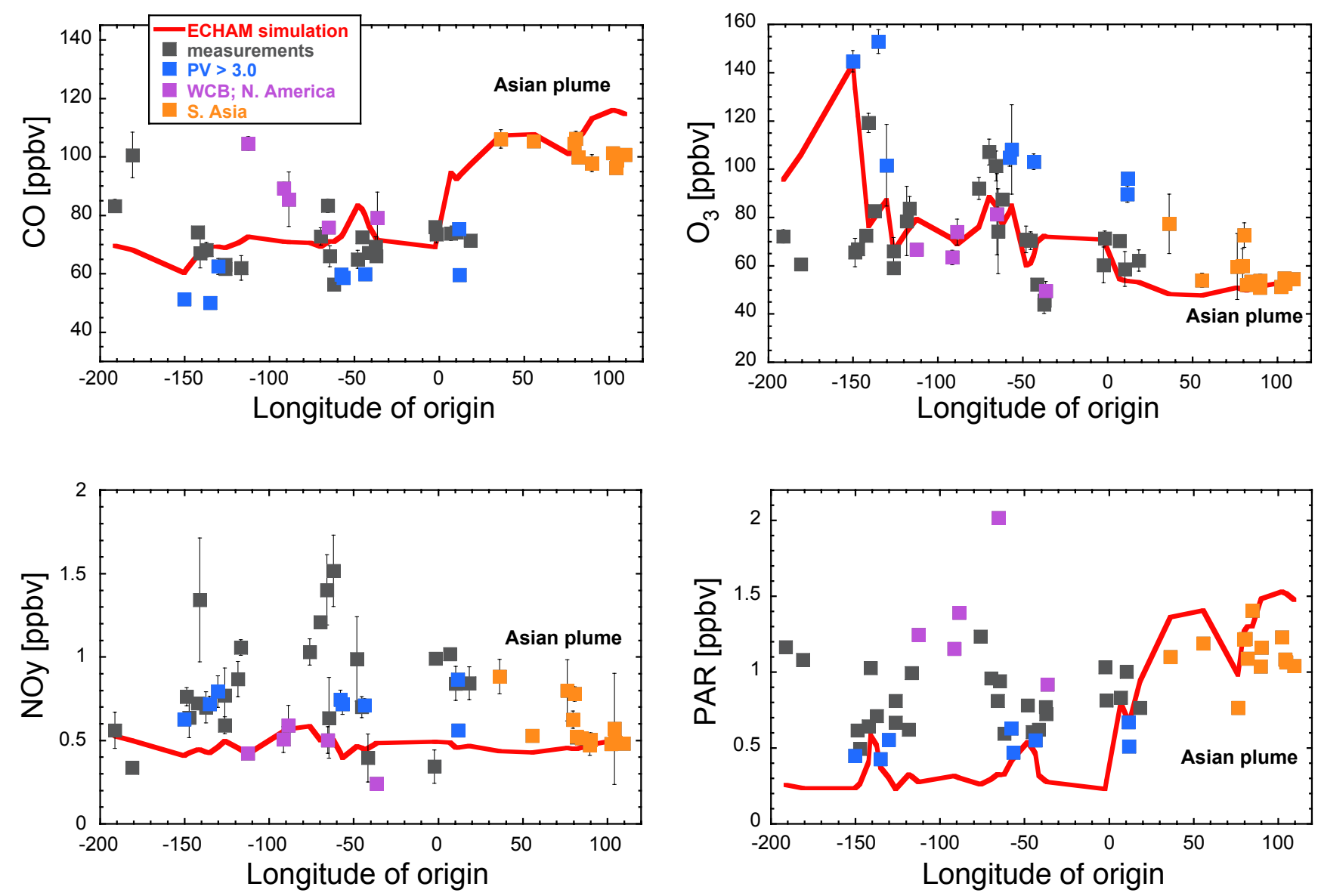

Fig. 10. Comparison between simulated and observed longitudinal gradients of $\mathrm{CO}, \mathrm{O}_{3}, \mathrm{NO}_{\mathrm{y}}$ and $\mathrm{C}_{2}-\mathrm{C}_{5}$ alkanes (paraffin's; PAR). The model output is shown by the solid line (weighted fit through the model output). The error bars on the measurement points of $\mathrm{CO}, \mathrm{O}_{3}$ and $\mathrm{NO}_{\mathrm{y}}$ depict the measured variability ( $1 \sigma$ standard deviation).

\subsection{Simulated source contributions to $\mathrm{O}_{3}$ and $\mathrm{CO}$}

In Roelofs et al. (2003) ECHAM4 is used to investigate contributions to upper tropospheric $(6-13 \mathrm{~km}$ altitude) concentrations of $\mathrm{O}_{3}$ from different source regions, being eastern and western Europe, Africa, India, South Asia, North America, lightning and the stratosphere. Here we extend the anal- ysis to CO. The simulated source contributions are shown as function of longitude of origin derived from the ECMWF 10day back trajectory analysis in Fig. 11. Older air masses that could not be attributed to one of the source regions are defined as "background", which also contributes up about $25 \%$ to the tropospheric ozone column. We focus specifically on the contributions of South Asia (India and Southeast Asia) 

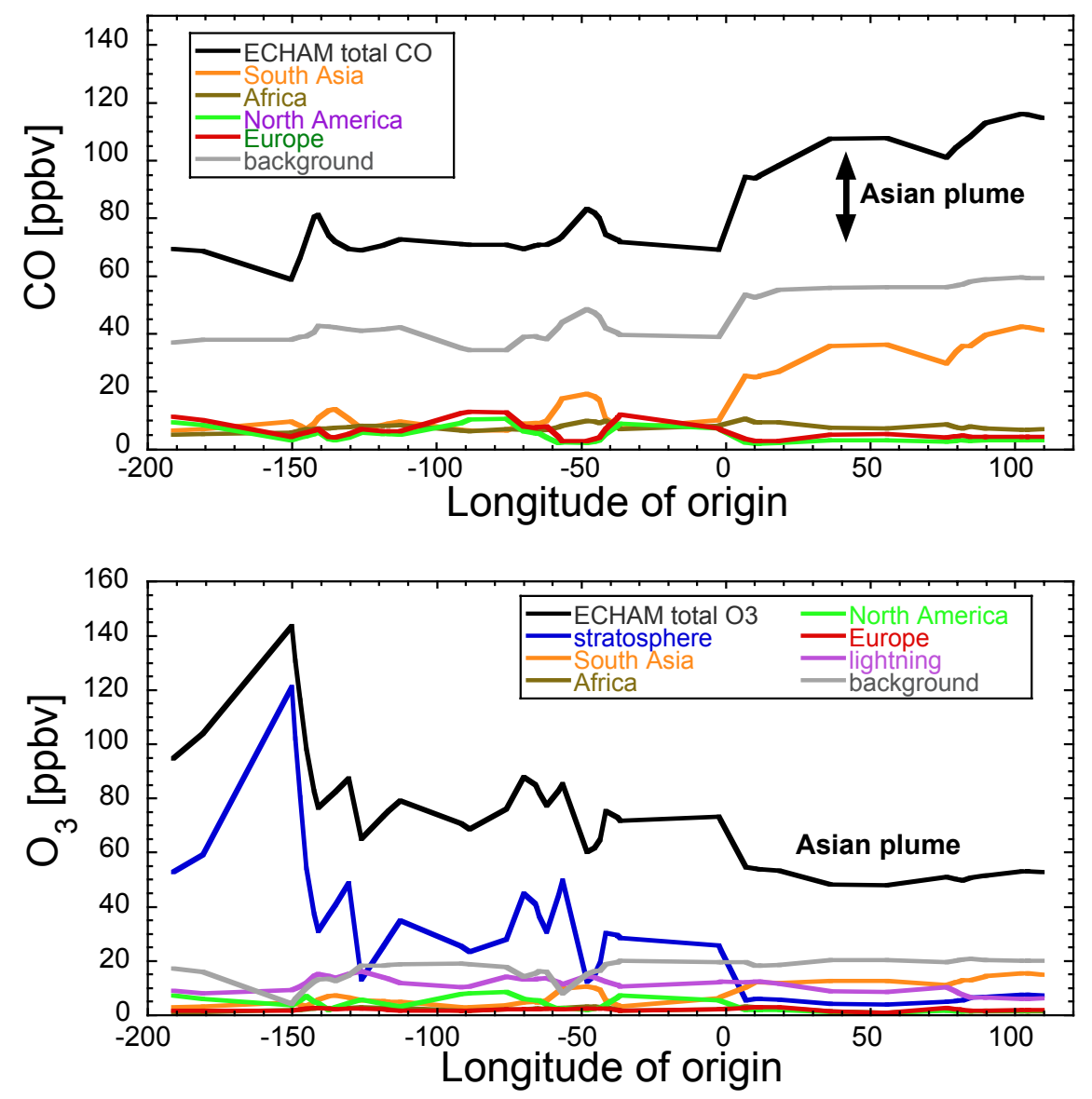

Fig. 11. Simulated source contributions to $\mathrm{CO}$ and $\mathrm{O}_{3}$ as function of longitude of origin (deduced from 10-day backward analysis) computed for the times and locations of air samples collected during 2 and 22 August in the upper troposphere ( $>6 \mathrm{~km})$. Shown is a weighted fit through the model data.

to $\mathrm{O}_{3}$ and $\mathrm{CO}$ in the Asian plume. About 10 to $16 \mathrm{ppbv}$ or $20-30 \%$ of total $\mathrm{O}_{3}$ and 28 to $44 \mathrm{ppbv}$ or $30-40 \%$ of $\mathrm{CO}$ in the Asian plume can be attributed to recent emissions from South Asia. The second largest contributor to ozone in the Asian plume appears to be lightning $\mathrm{NO}_{\mathrm{x}}$ associated with the ASM, contributing 6 to $11 \mathrm{ppbv}(10-20 \%)$ to total $\mathrm{O}_{3}$ in the plume. In the westerlies, the simulated ozone concentration variability appears to be associated with downward mixing of stratospheric air. The NMHC concentration in the westerlies is underestimated by the model (see Table 4). As mentioned earlier, the simulated stratospheric contribution may be overestimated thereby artificially reducing the photochemical ozone production in polluted air masses from the North American continent.

\subsection{Impact of increasing Asian $\mathrm{NO}_{\mathrm{x}}$ emissions on tropo- spheric ozone}

South Asia (notably India and China) is the fastest growing region in the world in terms of population and economic development. This may have a significant impact on a hemispheric scale on the atmospheric levels of ozone and ozone precursors (Lelieveld et al., 2001; Lelieveld and Dentener, 2000; Hauglustaine and Brasseur, 2001). A relatively large increase is expected for Asian $\mathrm{NO}_{\mathrm{x}}$-emissions in the next 25 years, due to the expected strong increase of fossil fuel use replacing biofuels (wood, dung and agricultural waste). Fossil fuel combustion generally produces lower $\mathrm{CO}$ and unburned hydrocarbon emissions than smoldering biofuel burning, but is more strongly $\mathrm{NO}_{\mathrm{x}}$-producing because of higher temperature and pressure conditions. Assuming the IPCC IS92a growth emission scenario for a future (2025) atmospheric chemistry simulation with the ECHAM4 model, it was found that $\mathrm{O}_{3}$ in the Asian plume increases with $\sim 7 \mathrm{ppbv}$, which is $\sim 14 \%$ of the present concentration. We note that this increase is only $\leq 1$ ppbv larger than in a future model run in which only $\mathrm{NO}_{\mathrm{x}}$ emissions are assumed to increase, illustrating again the $\mathrm{NO}_{\mathrm{x}}$-limited conditions for photochemical ozone production in the Asian plume. Consistently, the correlation between observed ozone and total $\mathrm{C}_{2}-\mathrm{C}_{7} \mathrm{NMHC}$ concentrations is insignificant in the Asian plume, whereas in the westerly plume a hydrocarbon-limited regime appears to dominate, as can be seen in Fig. 12. 


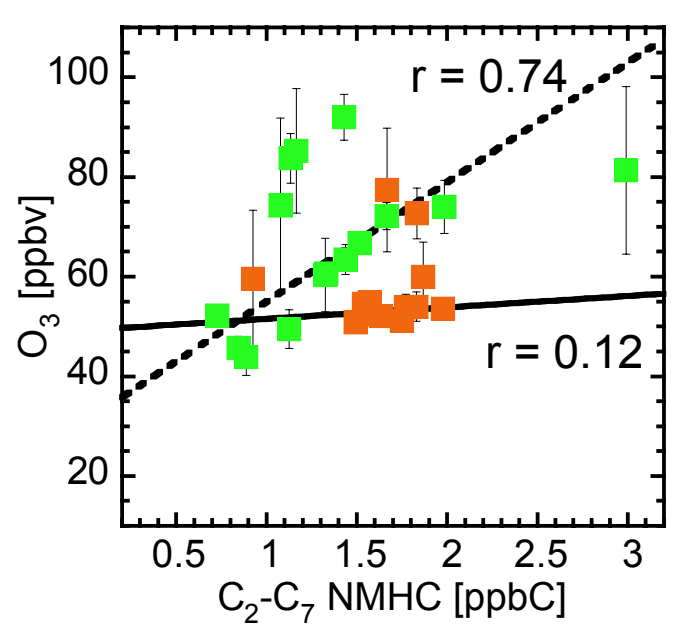

Fig. 12. Correlation between observed $\mathrm{O}_{3}$ and $\mathrm{NMHC}$ in the Asian plume (orange) and westerly plume (green).

Our results agree with the model study of Stevenson et al. (2002), who simulated an ozone increase around $20 \%$ in the Asian plume over the Mediterranean for ozone precursor emissions representative of 2030. Tropospheric ozone is an effective greenhouse gas accounting currently for $\sim 0.4 \mathrm{~W} \mathrm{~m}^{-2}$ of the global mean radiative forcing of climate, which is about $25 \%$ of the forcing by $\mathrm{CO}_{2}$ (Lelieveld and Dentener, 2000). This is relatively small compared to the radiative forcing due to the backscatter of solar radiation caused by anthropogenic aerosols over the eastern Mediterranean resulting in a cooling of about $6.6 \mathrm{~W} \mathrm{~m}^{-2}$ at the top of the atmosphere (Lelieveld et al., 2002; Markovic et al., 2002). While the radiative forcing of tropospheric ozone is likely to increase in the future, the aerosol radiative effect might decrease as result of the implementation of cleaner combustion and fuel technologies and emission reduction measures in Europe. On the other hand, higher ozone levels in the future Asian plume affect the tropospheric ozone budget over Northern Africa and the (sub-)tropical Atlantic as well, contributing to the oxidizing capacity of the atmosphere over these regions.

\section{Summary and conclusions}

Deep convection associated with the Asian summer monsoon followed by long-range transport carries Asian pollution towards the eastern Mediterranean and northern Africa. Model studies indicate that this Asian plume is a yearly recurrent phenomenon over the Mediterranean. We present observations of trace species during MINOS in August 2001, showing that the Asian plume has a large impact on the chemical composition of the upper troposphere over the eastern Mediterranean. Enhanced levels of $\mathrm{CO}$, and hydrocarbons were found to be comparable to or higher than those found in westerly air masses, containing pollution from the North American continent. The Asian plume shows a signature of biomass burning (notably from the use of biofuels) by enhanced concentrations of $\mathrm{CO}$, acetylene, benzene, acetone, acetonitrile, methyl chloride and chloroform, in agreement with observations from the 1999 INDOEX campaign in outflow from India. The mean photochemical age of the encountered Asian pollution is estimated to be about 2 weeks, based on the comparison of emission ratios relative to $\mathrm{CO}$ from MINOS with ER's derived from INDOEX results, consistent with trajectory analysis. Acetone levels in the Asian plume are of the same magnitude as those observed in the westerlies, exceeding upper tropospheric background levels. On the other hand, methanol levels are higher in the Asian plume, probably related to emissions from Asian biofuel use. The new automobile air conditioning agent HFC-134a was significantly enhanced above background values in air masses originating from North America, serving as a tracer for western pollution. The extensive fossil fuel use in North America is associated with relatively large $\mathrm{CO}_{2}$ concentrations in the westerlies, correlating with enhanced HFC-134a.

In spite of high pollution levels in the Asian plume, ozone concentrations are still relatively low ( $\sim 55 \mathrm{ppbv})$ and show no clear relationship with higher hydrocarbons. This suggests a $\mathrm{NO}_{\mathrm{x}}$-limited photochemical ozone production regime. Model simulations, carried out with a tropospheric chemistry-climate model, indicate that the expected increase of Asian emissions in the next few decades may enhance photochemically produced ozone in the Asian plume by about $14 \%$.

The influence of recent stratosphere-to-troposphere exchange is absent in the Asian plume, but appears to have affected the chemical composition of air masses from westerly origin. STE causes a significant enhancement of ozone concentrations while $\mathrm{CO}$, and hydrocarbon concentrations are decreased. The Asian plume, on the other hand, represents a large reservoir of pollutants near the tropopause. Observations in the lowermost stratosphere over the Aegean Sea suggest that troposphere-to-stratosphere transport of Asian pollution may have occurred during MINOS.

Acknowledgement. We gratefully acknowledge the excellent cooperation with the DLR Falcon team. We thank R. Scheele from the KNMI for computing the 10-day back trajectories. We are grateful to S. A. Montzka of NOAA/CMDL for providing halocarbon reference measurements.

\section{References}

Alternative Fluorocarbons Environmental Acceptability Study (AFEAS): Production and Sales of Fluorocarbons on http://www. afeas.org/production_and_sales.html, Arlington, VA, USA, 2002. Atkinson, R. A., Baulch, D. L., Cox, R. A., Hampson-Jr., R. F., Kerr, J. A., Rossi, M. J., and Troe, J.: Evaluated kinetic, photochemical data and heterogeneous data for atmospheric chemistry - Supplement V, J. Phys. Chem. Ref. Data, 21, 521, 1997. 
Brunner, D., Staehelin, J., Jeker, D., Wernli, H., and Schumann, U.: Nitrogen oxides and ozone in the tropopause region of the Northern Hemisphere: Measurements from commercial aircraft in 1995 / 1996 and 1997, J. Geophys. Res., 106, 27 673-27 699, 2001.

Chen, P.: Isentropic cross-tropopause mass exchange in the extratropics, J. Geophys. Res., 100, 16661-16 673, 1995.

Cooper, O. R., Moody, J. L., Parrish, D. D., Trainer, M., Ryerson, T. B., Holloway, J. S., Hübler, G., Fehsenfeld, F. C., Oltmans, S. J., and Evans, M. J.: Trace gas signatures of the airstreams within North Atlantic cyclones: Case studies from the North Atlantic Regional Experiment (NARE'97) aircraft intensive, J. Geophys. Res., 106, 5437-5456, 2001.

de Gouw, J. A., Warneke, C., Scheeren, H. A., van der Veen, C., Bolder, M., Scheele, M. P., Williams, J., Wong, S., Lange, L., Fischer, H., and Lelieveld, J.: Overview of the measurements onboard the Citation aircraft during the Intensive Field Phase of INDOEX, J. Geophys. Res., 106, 28 453-28 467, 2001

Dethof, A., O'Neill, A., and Slingo, J.: Quantification of the isentropic mass transport across the dynamical tropopause, J. Geophys. Res., 105, 12 279-12 293, 2000.

Energy Information Administration (EIA): Emissions of Greenhouse gases in the United States 1997 - Halocarbons and Other Gases on http://www.eia.doe.gov/oiaf/1605/gg98rpt/ halocarbons.html, Washington, DC, USA.

Fischer, H., de Reus, M., de Gouw, J., Warneke, C., Schlager, H., and Minikin, A.: Deep convective injection of boundary layer air into the lowermost stratosphere at mid-latitudes, Atmos. Chem. Phys., 2, 739-745, 2003.

Galballi, I. E. and Kirstine, W.: The production of methanol by flowering plants and the global cycle of methanol, J. Atmos. Chem., 3, 195-229, 2002.

Good, P., Giannakopoulos, C., O'Connor, F. M., Arnold, S. R., de Reus M., and Schlager, H.: Constraining tropospheric mixing timescales using airborne observations and numerical models, Atmos. Chem. Phys., 3, 1023-1035, 2003.

Gros, V., Williams, J., Krol, M., Berresheim, H., Salisbury, G., Hofmann, R., and Lelieveld, J.: Investigating source origins and photochemical processing of the VOCs during the MINOS-2001 campaign, Atmos. Chem. Phys., 3, 1223-1235, 2003.

Hastenrath, S.: Climate dynamics of the tropics, Atmospheric Sciences Library, volume 8, Kluwer Acadamic Publishers, Dordrecht, the Netherlands, 1991.

Hauglustaine, D. A., and Brasseur, G. P.: Evolution of tropospheric ozone under anthropogenic activities and associated radiative forcing of climate, J. Geophys. Res., 106, 32 337-32 360, 2001.

Heland, J., Ziereis, H. Schlager, H., Hauser, C., Stock, P., Roiger, A., de Reus, M., Traub, M., and Roelofs, G. -J.: Aircraft observations of trace gas correlations during MINOS 2001 - case studies on the origin of air masses, Atmos. Chem. Phys. Discuss., 3, 1991-2026, 2003.

Houweling, S., Dentener, F., Lelieveld, J., Walter, B, and Dlugokencky, E.: The modeling of tropospheric methane: How well can point measurements be reproduced by a global model?, J. Geophys. Res., 105, 8981-9002, 2000.

Hsu, H., Terng, C., and Chen, C.: Evolution of Large-Scale Circulation and Heating during the first transition of Asian summer monsoon, J. Climate, 12, 793-810, 1999.

Jacob, D. J., Field, B. D., Jin, E. M., Bey, I., Li, Q., Logan, J. A., and
Yantosca, R. M.: Atmospheric budget of acetone, J. Geophys. Res., 107, doi: 10.1029/201JD000694, 2002.

Jeker, D. P., Pfister, L., Thompson, A. M., Brunner, D., Boccipio, D. J., Pickering, K. E., Wernli, H., Kondo, Y., and Staehelin, J.: Measurements of nitrogen oxides at the tropopause: Attribution to convection and correlation with lightning, J. Geophys. Res., 105, 3679-3700, 2000.

Jobson, B. T., Parrish, D. D., Goldan, P., Kuster, W., Fehsenfeld, F. C., Blake, D. R., Blake, N. J., and Niki, H.: Spatial and temporal variability of non-methane hydrocarbon mixing ratios and their relation to photochemical lifetime, J. Geophys. Res., 103, 13 557-13 567, 1998.

Kanakidou, M., Dentener, F. J., and Crutzen, P. J.: A global threedimensional study of the fate of HCFCs and HFC-134a in the troposphere, J. Geophys. Res., 100, 18 781-18 880, 1995.

Keene, W. C., Khalil, M. A. K., Erickson, D. J., McCulloch, A., Greadel, T. E., Lobert, J. M., Aucott, M. L., Gong, S. -L., Harper, D. B., Kleinman, G., Midley, P., Moore, R. A., Seuzaret, C., Sturges, W. T., Benkovitz, C. M., Koropalov, V., Barrie, L. A., and $\mathrm{Li}$, Y. -F.: Composite global emissions of reactive chlorine from anthropogenic and natural sources: The Reactive Chlorine Emissions Inventory, J. Geophys. Res., 104, 8429-8440, 1999.

Kouvarakis, K., Tsigaridis, K., Kanakidou, M., and Mihalopoulos, N.: Temporal variations of surface regional background ozone over Crete island in the southeast Mediterranean, J. Geophys. Res., 105, 4399-4407, 2000.

Lawrence, M. G., Rasch, P. J., von Kuhlmann, R., Williams, J., Fischer, H., de Reus, M., Lelieveld, J., Crutzen, P. J., Huntrieser, H., Heland, J., Stohl, A., Forster, C., Schultz, M., Stier, P., and Dickerson, R.: Chemical weather forecasting as a tool for field campaign planning: Predictions and observations of large-scale features during INDOEX, MINOS, and CONTRACE, Atmos. Chem. Phys., 3, 267-289, 2003.

Lee-Taylor, J. M., Brasseur, G. P., and Yokouchi, Y.: A preliminary three-dimensional global model study of atmospheric methyl chloride distributions, J. Geophys. Res., 106, 34 221-34 233, 2001.

Lelieveld, J. and Dentener, F. J.: What controls tropospheric ozone?, J. Geophys. Res., 105, 3531-3551, 2000.

Lelieveld, J., Crutzen, P. J., Ramanathan, V., Andreae, M. O., Brenninkmeijer, C. A. M., Campos, T., Cass, G. R., Dickerson, R. R., Fischer, H., de Gouw, J. A., Hansel, A., Jefferson, A., Kley, D., de Laat, A. T. J., Lal, S., Lawrence, M. G., Lobert, J. M., Mayol- Bracero, O., Mitra, A. P., Novakov, T., Oltmans, S. J., Prather, K. A., Reiner, T., Rodhe, H., Scheeren, H. A., Sikka, D., and Williams, J.: The Indian Ocean Experiment: widespread air pollution from South and South-East Asia, Science, 291, 10311036, 2001.

Lelieveld, J., Berresheim, H., Bormann, S., Crutzen, P. J., Dentener, F. J., Fischer, H., Feichter, J., Flatau, P. J., Heland, J., Holzinger, R., Kormann, R., Lawrence, M. G., Levin, Z., Markowicz, K. M., Mihalopoulos, N., Minikin, A., Ramanathan, V., de Reus, M., Roelofs, G. -J., Scheeren, H. A., Scaire, J., Schlager, H., Schultz, M., Siegmund, P., Steil, B., Stephanou, E. G., Stier, P., Traub, M., Warneke, C., Williams, J., and Ziereis, H.: Global air pollution crossroads over the Mediterranean, Science, 298, 794 799, 2002.

Lindinger, W., Hansel, A., and Jordan, A.: On-line monitoring of volatile organic compounds at pptv level by means of Proton- 
Transfer-Reaction Mass Spectrometry (PTR-MS) - Medical applications, food control, and environmental research, Int. J. Mass Spectrom. Ion Processes, 173, 191-241, 1998.

Markowicz, K. M., Flatau, P. J., Ramana, M. V., Crutzen, P. J., and Ramanathan, V.: Absorbing Mediterranean aerosols lead to a large reduction in the solar radiation at the surface, Geophys. Res. Lett., 29, 20, 1968, doi: 10.1029/2002GL015767, 2002.

Matsueda, H., Inoue, H. Y., and Ishii, M.: Aircraft observation of carbon at 8-13 km altitude over the western Pacific from 1993 to 1999, Tellus, 54B, 1-21, 2002.

Millan, M. M., Salvador, R., Mantilla, E., and Kallos, G.: Photooxidant dynamics in the Mediterranean basin in summer: Results from European research projects, J. Geophys. Res., 102, 88118823, 1997.

Minikin, A., Mihalopolous, N., Economou, C., Sciare, J., Schneider, J., Levin, Z., Teller, A., Ganor, E., Stein, C., Berresheim, H., de Reus, M., Rasch, P., Chourdakis, G., and Papayannis, A.: Tropospheric vertical profiles of aerosol properties in the eastern Mediterranean region in summer 2001 (MINOS campaign), poster at the International Global Atmospheric Chemistry Conference (IGAC), Crete, Greece, 2002.

Olivier, J. G. J, Bouwman, A. F., van der Maas, C. W. M., M. Berdowski, J. J., Veldt, C., Bloos, J. P. J.,Visschendijk, A. J. H., Zandveld P. Y. J., and Haverlag, J. L.,: Description of EDGAR version 2.0. Report No. 771060 002. Bilthoven (The Netherlands), RIVM, 1996.

Prinn, R. G, Weiss, R. F., Fraser, P. J., Simmonds, P. G., Cunnold, D. M., Alya, F. N., O’Doherty, S., Salameh, P., Miller, B. R., Huang, J., Wang, R. H. J., Harley, D. E., Harth, C., Steele, L. P., Sturrock, G., Midley, P. M., and McCulloch, A.: A history of chemically and radiatively important gases in air deduced from ALE/GAGE/AGAGE, J. Geophys. Res., 105, 17 751-17 792, 2000.

Roelofs, G.-J. and Lelieveld, J.: Tropospheric ozone simulation with a global chemistry-climate model: Influence of higher hydrocarbon chemistry, J. Geophys. Res., 105, 22 697-22 711, 2000.

Roelofs, G.-J., Scheeren, H. A., Kentarchos, T., and Lelieveld, J.: Distribution and origin of ozone in the eastern Mediterranean free troposphere, Atmos. Chem. Phys., 3, 1199-1210, 2003.

Scheele, M. P., Siegmund, P. C., and van Velthoven, P. F. J.: Sensitivity of trajectories to data resolution and its dependence on the starting point: In or outside a tropopause fold, Meteorol. Appl., 3, 267-273, 1996.
Scheeren, H. A., Lelieveld, J., de Gouw, J. A., van der Veen, C., and Fischer, H.: Methyl chloride and other chlorocarbons in polluted air during INDOEX, J. Geophys. Res., 107, doi: 10.1029/2001JD001121, 2002.

Singh, H. B., Kanakidou, M., Crutzen, P. J., and Jacob, D. J.: High concentrations and photochemical fate of oxygenated hydrocarbons in the global troposphere, Nature, 378, 50-54, 1995.

Stevenson, D., Johnson, C., Collins, B., and Derwent, D.: Projected changes in global tropospheric ozone to 2030, poster at the International Global Atmospheric Chemistry (IGAC) conference, Crete, Greece, 2002.

Stohl, A. and Trickl, T.: A textbook example of long-range transport: Simultaneous observations of ozone maxima of stratospheric and North American origin in the free troposphere over Europe, J. Geophys. Res., 104, 30 445-30 462, 1999.

Stohl A., Haimberger, L., Scheele M. P., and Wernli H.: An intercomparison of results from three trajectory models, Meteorol. Appl., 8, 127-135, 2001.

Strahan, S. E., Douglas, A. R., Nielsen, J. E., and Boering, K. A.: The $\mathrm{CO}_{2}$ seasonal cycle as a tracer of transport, J. Geophys. Res., 103, 13 729-13 741, 1998.

Traub, M., Fischer, H., de Reus, M., Kormann, R., Heland, J., Ziereis, H., Schlager, H., Holzinger, R., Williams, J., Warneke, C., de Gouw, J., and Lelieveld, J.: Chemical characteristics assigned to trajectory clusters during the MINOS campaign, Atmos. Chem. Phys., 3, 459-468, 2003.

Veldt, C. and Berdowski, J. J. M.: GEAI-note on the combustion of biomass fuels (emission factors for $\mathrm{CO}, \mathrm{CH}_{4}$ and NMVOC), TNO Rep. R94/218, Inst. Of Environ. Sci., Neth. Org. for Appl. Sci. Res., Delft, The Netherlands, 1995.

Wienhold, F. G., Fischer, H., Hoor, P., Wagner, V., Königstedt, R., Harris, G. W., Anders, J., Grisar, R., Knothe, M. Riedel, W. J. Lübken, F. -J., and Schilling, T.: TRISTAR - a tracer in-situ TDLAS for atmospheric research, Appl. Phys. B, 67, 411-417, 1998.

World Resources Institute (WRI): Global Motor Vehicle Fleet on http://www.wri.org/wr-98-99/autos2.htm, Washington DC, USA, 2002.

Yokouchi, Y., Nojiri, Y., Barrie, L. A., Toom-Sauntry, D., Machida, T., Inuzka, Y., Akimoto, H., Li, H. -J., Fujinuma, Y., and Aoki, S.: A strong source of methyl chloride to the atmosphere from tropical coastal land, Nature, 403, 295-298, 2000.

Ziereis, H., Schlager, H., Schulte, P., Köhler, I., Marquardt, R., and Feigl, C.: In situ measurements of the $\mathrm{NO}_{\mathrm{X}}$ distribution and variability over the eastern North Atlantic, J, Geophys. Res., 104, 16 021-16 032, 1999. 